\title{
Three-dimensional geologic mapping to assess geothermal potential: examples from Nevada and Oregon
}

\author{
Drew L. Siler ${ }^{*}$, James E. Faulds ${ }^{2}$, Nicholas H. Hinz ${ }^{2,3}$, Gregory M. Dering ${ }^{2,4}$, Joel H. Edwards ${ }^{2,5}$ and Brett Mayhew ${ }^{2}$
}

\author{
*Correspondence: \\ dsiler@usgs.gov \\ 1 U.S. Geological Survey, \\ 345 Middlefield Rd MS 989, \\ Menlo Park, CA 94025, USA \\ Full list of author information \\ is available at the end of the \\ article
}

\begin{abstract}
Geologic structure plays an important role in controlling fluid flow in geothermal systems. In particular, very complex structural settings, consisting of many closely spaced and intersecting faults, host many geothermal systems. To elucidate the key geologic factors that affect fault-controlled geothermal circulation, it is critical to precisely characterize the structural and stratigraphic geometries in these complex settings. Here, we present a methodology and the results of 3D geologic analyses of two geothermal systems in the Basin and Range, USA. This methodology is a quantitative and geologically focused technique that can be used to precisely characterize geothermal areas, in a time when future geothermal growth demands increased exploration precision and efficiency. Surficial and subsurface geologic and geophysical data are synthesized in the construction of detailed 3D geologic maps of geothermal areas. Based on these 3D geologic maps, we examine several geologic attributes that control permeability development and geothermal fluid flow along faults. We use the stress state of faults and the distribution of structural discontinuities (i.e., fault intersections and fault terminations) to identify locations of upflow along faults in these geothermal systems. These results and the methodology presented herein are directly applicable to structurally controlled geothermal fields in the Basin and Range and worldwide. As development focus shifts toward blind geothermal resources, integration of precisely characterized subsurface structural information into exploration methods will be increasingly critical to continued growth in geothermal exploration and development.
\end{abstract}

\section{Introduction}

In this paper, we present a methodology for three-dimensional (3D) analysis of the structural and geologic controls on permeability development and the transmission of fluids in geothermal systems. We present these methods through examples from two geothermal fields, demonstrating the use of these methods in developing data-driven and testable conceptual models of geothermal processes.

Faults and interconnected networks of faults and fractures can serve as pathways for upwelling in geothermal fields. This is particularly true in both magmatic and nonmagmatic geothermal systems occupying extensional and transtensional domains in which normal and strike-slip faults serve as fluid conduits (Moeck 2014; Moeck and Beardsmore 2014). The most conductive fault networks typically occur within complex 
structural interaction areas (Curewitz and Karson 1997; Faulds et al. 2006, 2011; Faulds and Hinz 2015). Within such areas, the most productive fluid upwelling zones may be confined to narrow conduits, perhaps tens to hundreds of meters wide, along a single fault or a small subset of faults (e.g., Caine et al. 1996, 2010; Caine and Forster 1999; Fairley et al. 2003; Fairley and Hinds 2004; Mitchell and Faulkner 2012; Meller and Kohl 2014). The relatively small extent of productive upwelling zones is a significant challenge to the characterization of and exploration for geothermal resources. To facilitate the continued growth of utilization of geothermal resources in structurally controlled systems, advanced tools capable of characterizing fault systems at this fine scale are needed. Here, we use detailed 3D geologic mapping and quantitative geologic analyses to determine specific volumes in the subsurface that are most prospective for hosting geothermal upwelling. This type of analysis can be used to iteratively develop and adapt robust 3D conceptual models of geothermal processes during exploration, thereby helping to increase precision and efficiency to geothermal development.

Historically, many geothermal systems have been discovered and developed through drilling adjacent to surface geothermal features (e.g., fumaroles, hot springs, geothermal deposits) or known thermal anomalies. Supplementary to the surface thermal information, geophysical data, geologic data, fault mapping, and other tools are used to characterize subsurface geologic structure and support drilling decisions. In the USA, however, the future growth potential in geothermal development that is indicated by national resource assessments (e.g., Williams et al. 2008) depends on development of new, yet undiscovered geothermal systems. Many of these may be 'blind' or have no thermal expression, fluid expression, or geothermal deposits at the surface. In other words, future growth in geothermal development requires that exploration techniques are adapted to current needs so that they can be, among other things, less dependent on information from surface geothermal features. Along these lines, it is imperative to integrate precisely characterized 3D geologic and structural features in any analysis of geothermal processes.

In this paper, we detail methods for 3D structural and geologic analysis and their use to identify areas of the subsurface with the appropriate characteristics for permeability and the transmission of fluids in geothermal systems. To fully understand the complex $3 \mathrm{D}$ geologic relationships in geothermal fields, $1 \mathrm{D}$ and 2D data must be synthesized into 3D geologic maps (e.g., Jachens et al. 2001; Phelps et al. 2008). Hydrocarbon exploration has long relied on the integration of geological and geophysical datasets in 3D for drilling target selection and resource estimation (Calcagno et al. 2008; Houlding 2012; Lindsay et al. 2013). Adapting a 3D mapping approach to fault-controlled geothermal systems, as we have done herein, can only be effective if geological characterization is sufficiently detailed to constrain structural and stratigraphic relationships at a scale that is relevant to geothermal processes, i.e., the tens-of-meter scale (e.g., Caine et al. 1996, 2010; Caine and Forster 1999; Fairley et al. 2003; Fairley and Hinds 2004; Sanderson and Zhang 2004; Mitchell and Faulkner 2012; Meller and Kohl 2014). The methods presented herein adapt existing techniques that have been developed over several decades in oil and gas and minerals exploration (e.g., Calcagno et al. 2008; Houlding 2012; Lindsay et al. 2013) and build upon previous 3D characterization efforts in geothermal systems (Jolie et al. 2015a, b; Siler et al. 2016a). Our methods have been developed through 


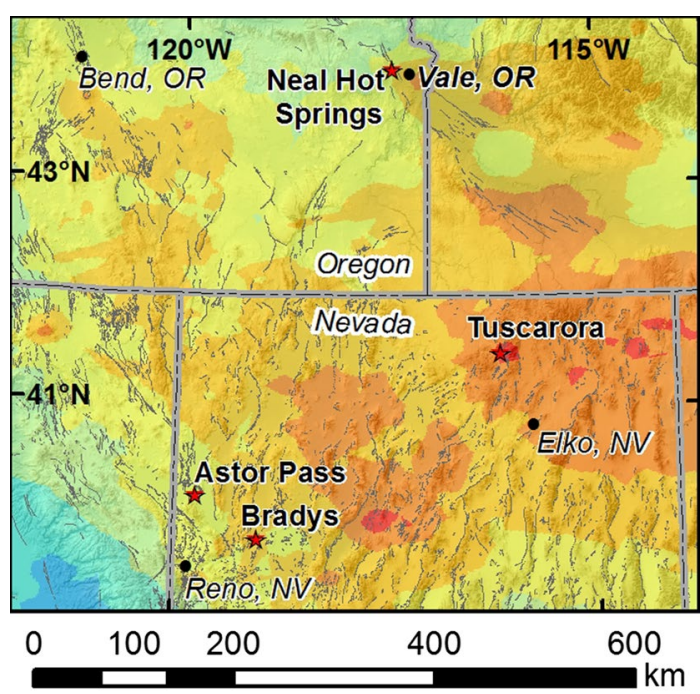

Heat flow $\left(\mathrm{mW} / \mathrm{m}^{2}\right)$

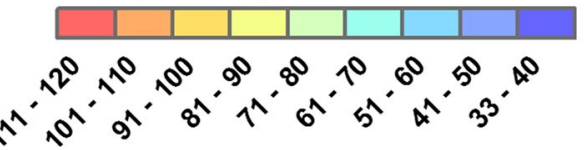

Fig. 1 Regional heat flow map showing the locations of the Astor Pass, Nevada; Bradys, Nevada; Neal Hot Springs, Oregon; and Tuscarora, Nevada geothermal systems that are referenced in this study. Modeled heat flow data from Williams and DeAngelo (2011). Faults from the U.S. Geological Survey Quaternary Fault and Fold Database (U.S. Geological Survey 2006)

analyses of several geothermal systems in northern Nevada and eastern Oregon (Fig. 1) and is specifically focused on detailed 3D mapping of fault systems and other geologic relationships that pertain to geothermal circulation.

Following the classification of Moeck and Beardsmore (2014) and Moeck (2014), the present work is most directly applicable to geothermal systems in which geologic structure plays a dominant role in channeling fluid upwelling, i.e., structurally (or fault-) controlled geothermal systems. This can pertain to both magmatic and amagmatic systems, occurring in a number of localities worldwide including, the Basin and Range (examples herein), East African Rift system, Turkey, the Rhine Graben, and Iceland (Moeck 2014; Moeck and Beardsmore 2014).

\section{Geothermal systems in the western USA}

Throughout the western USA and around the world, permeability in many geothermal systems is structurally controlled (Flóvenz and Sæmundsson 1993; Bibby et al. 1995; Curewitz and Karson 1997; Arnadottir et al. 2003; Rowland and Sibson 2004; Faulds et al. 2006, 2011; Wallis et al. 2012; Moeck 2014; Moeck and Beardsmore 2014). That is, faults and interconnected networks of faults and fractures serve as pathways for circulating fluids. Crustal heat flow across much of the Basin and Range province is generally high relative to typical continental crustal heat flow. For example, heat flow in the northern Basin and Range ranges from $\sim 85$ to $110 \mathrm{~mW} / \mathrm{m}^{2}$ (Lachenbruch and Sass 1977; Blackwell et al. 1991; Williams and DeAngelo 2011), with geothermal gradients 
of $\sim 35-40^{\circ} \mathrm{C} / \mathrm{km}$ (Nathenson and Guffanti 1988). This temperature distribution suggests that geothermal fluids circulate to minimum depths of $\sim 3-5 \mathrm{~km}$ to attain the production temperatures that have been measured in geothermal fields (based on publicly available data, Nevada Division of Minerals). The regionally high heat flow throughout the northern Basin and Range suggests that the occurrence of a geothermal system in a certain location is primarily controlled by the localization of structurally controlled pathways for fluids upwelling from these depths.

A survey of the $\sim 450$ known geothermal systems in the extensional and transtensional domains of the Great Basin region, including the systems presented herein, has shown that a handful of specific structural geometries control the location of geothermal upwelling in nearly all systems (Faulds et al. 2006, 2011). This and other worldwide examinations of the geologic characteristics of known geothermal systems (Curewitz and Karson 1997; Moeck 2014; Moeck and Beardsmore 2014) have laid the groundwork for the next generation of higher-resolution tools and techniques.

The most common settings for geothermal systems in the Great Basin region are fault terminations, fault step-overs, fault intersections, accommodation zones, displacement transfer zones, and pull-aparts (Faulds et al. 2006, 2011; Faulds and Hinz 2015). These are sites with inherent structural complexity, exemplified by a high local density of interconnected faults and fractures. Permeability is greater in these areas, and this is beneficial for the development and maintenance of fluid upflow pathways along faults (Faulds et al. 2006, 2013; Coolbaugh et al. 2007; Lechler and Coolbaugh 2007; Jolie et al. 2015a, b; Siler et al. 2018).

Like upwelling, downwelling and recharge may be controlled by permeability in complex structural interaction areas as well. However, modern recharge of meteoric fluids probably constitutes a relatively minor component of geothermal fluids in the Basin and Range. Oxygen isotope data suggest that many Basin and Range geothermal fluids are predominantly composed of older fluids, rather than modern meteoric fluids, which probably originated in the wetter Pleistocene (Flynn and Buchanan 1990; Smith et al. 2002). Additionally, as much as one-quarter of Basin and Range geothermal fluids may comprise deep, crustal-derived fluids, rather than meteoric fluids (Bergman et al. 2015 and references therein). Though modern downwelling may take advantage of faulted permeability pathways in magmatic geothermal systems and structurally controlled geothermal systems in other parts of the world (e.g., Stimac et al. 2015), it appears to not be an important aspect of Basin and Range geothermal systems, and so we do not evaluate downwelling and recharge in our characterization of the structural controls of geothermal circulation herein.

Structural interaction areas such as step-overs, fault intersections, accommodation zones, displacement transfer zones, and pull-aparts may span many to tens of square kilometers. Within these broad zones, the most productive fluid upwelling zones are highly localized, limited to narrow zones, tens to hundreds of meters wide, along a single fault or a small subset of faults. Fluid flow zones in geothermal production wells can be confined to even smaller scales, narrower than $\sim 1 \mathrm{~m}$ along the well path in some cases (based on publicly available data, Nevada Division of Minerals). This compartmentalization of permeability is probably controlled by lateral structural and lithologic variation within groups of faults or along discrete faults (Caine et al. 1996, 
2010; Caine and Forster 1999; Fairley et al. 2003; Fairley and Hinds 2004; Sanderson and Zhang 2004; Mitchell and Faulkner 2012; Meller and Kohl 2014). It is this structural compartmentalization that is critical to characterize in space to increase the precision and efficiency of geothermal exploration.

In addition to the localized nature of fluid flow zones, geothermal exploration and especially well targeting are complicated by the fact that detection of the thermal, geochemical, or geophysical signature of geothermal fluid in the subsurface may reveal relatively shallow geothermal outflow, rather than the location of the allimportant zone(s) of geothermal upwelling from depth (Fig. 2). Upwelling fluids may follow a number of different paths in the shallow subsurface. Fluids may, for example, flow directly to the surface and effuse adjacent to the controlling fault (Blackwell et al. 1999; Faulds et al. 2010b). Alternatively, upwelling fluids may be trapped beneath shallow impermeable layers and flow out at some distance to the controlling fault (Hinz et al. 2014) or have no surface expression at all (Faulds et al. 2010a; Nordquist and Delwiche 2013). In the shallow subsurface, upwelling fluids may also mix with shallow groundwater, masking the thermal and/or the geochemical signature of outflowing fluids. Upwelling fluids may also charge permeable stratigraphic horizons (Siler et al. 2016a). In many of these cases, the surface outflow, surface or near-surface temperature anomaly, or the geochemical signature of geothermal fluids may be located several kilometers away from the fluid upwelling zone. If fluid samples are available, the geochemical signature of thermal fluids can provide important information about upflow versus outflow (e.g., Goff et al. 2002). Understanding subsurface structural geometries is critical as well. To characterize the geologic controls on fault-hosted geothermal activity at the fine-scale dictated by the geologic variability, analyses must be detailed enough so that results at least approach the fine-scale

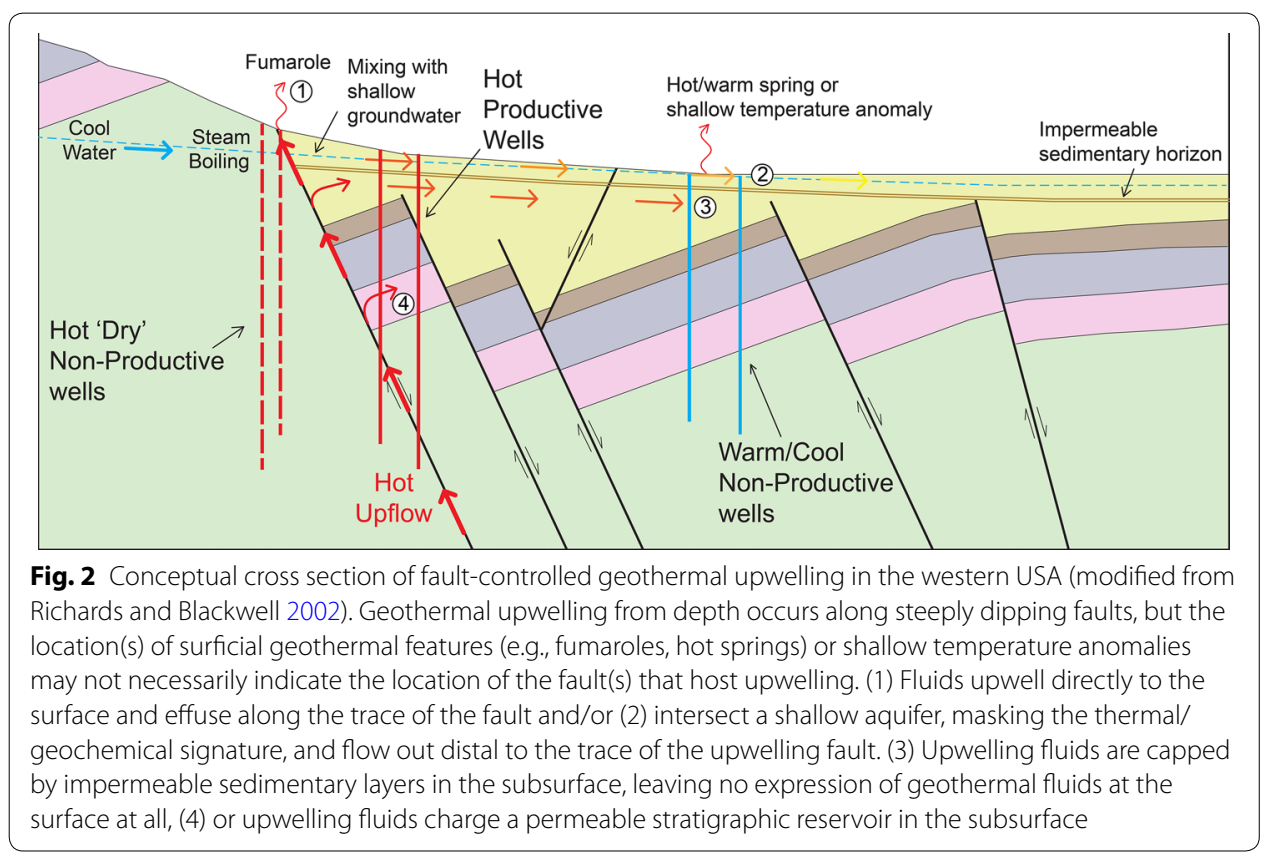


structural and geologic heterogeneity within fault systems. This is the key advancement presented in this paper.

The geothermal systems referred to in this study are Bradys, Nevada; Astor Pass, Nevada; Tuscarora, Nevada; and Neal Hot Springs, Oregon (Fig. 1). These systems were selected for several reasons. Firstly, each has abundant surface and subsurface data, therefore allowing for detailed 3D geologic characterization. Secondly, together they represent several of the structural settings that have been shown to be important hosts of geothermal fluid flow. Bradys (Faulds et al. 2010b, 2017, Jolie et al. 2015a, b, 2016; Siler et al. 2016b) and Neal Hot Springs (Edwards and Faulds 2012; Edwards 2013; Warren 2016) are hosted by step-overs in normal fault systems, similar to $32 \%$ of the known geothermal systems in the Great Basin (Faulds et al. 2006, 2011; Faulds and Hinz 2015). Astor Pass lies at the intersection between two major fault zones (Siler et al. 2016a), a structural setting that hosts $\sim 22 \%$ Great Basin systems (Faulds et al. 2006, 2011; Faulds and Hinz 2015). Tuscarora lies in an accommodation zone within a broad, regional stepover (Dering 2013; Dering and Faulds 2013a; Faulds et al. 2013). Accommodation zones constitute $\sim 8 \%$ of geothermal systems and $26 \%$ of systems developed for electricity generation in the Great Basin (Faulds et al. 2013). Tuscarora and Neal Hot also represent a range from relatively small to broad fault step-overs, respectively. Our results from these systems, therefore, constrain the 3D fault geometry at varying scales for the most common favorable structural settings for geothermal activity in the Basin and Range province. Results referred to from Bradys (Siler and Faulds 2013a; Jolie et al. 2015a, b, 2016; Siler et al. 2016b; Witter et al. 2016) and Astor Pass (Siler et al. 2012, 2016a; Siler and Faulds 2013a) have been published previously, whereas new results from Tuscarora, Nevada, and Neal Hot Springs, Oregon, are presented in detail herein.

\section{Methods: 3D geologic mapping}

3D geologic mapping is facilitated by integration of a variety of data types. Generally, the most important and readily available are a detailed geologic map, 2D interpretive geologic cross sections, 2D seismic reflection data, potential field geophysical data and modeling, and downhole lithologic data interpreted from well cuttings and/or core (Fig. 3). In the following sections, we describe the generalized 3D geologic mapping methodology used in the analysis of geothermal systems, which is similar to that used by Jolie et al. (2012, 2015b), Moeck et al. (2009a, b), and Siler et al. (2016a). The following methodology can be applied in a number of 3D software packages. A review of 3D geoscience software is beyond the scope of this paper, but the reader is directed to Houlding (2012), Jacobsen et al. (2011), and references therein for excellent reviews of 3D geologic modeling, including available software tools. The presentation of the methodology is followed by 3D geologic mapping results from Tuscarora, Nevada, and Neal Hot Springs, Oregon (Fig. 1).

\section{The geologic map}

Geologic mapping delineates rock types, structure, hydrothermal alteration, and other surface geothermal manifestations (Hinz and Faulds 2011; Hinz et al. 2011; Faulds et al. 2012, 2017; Dering and Faulds 2013b; Anderson et al. 2014), ideally encompassing all significant lithologic units projected at depth within the area. Defining the structural 


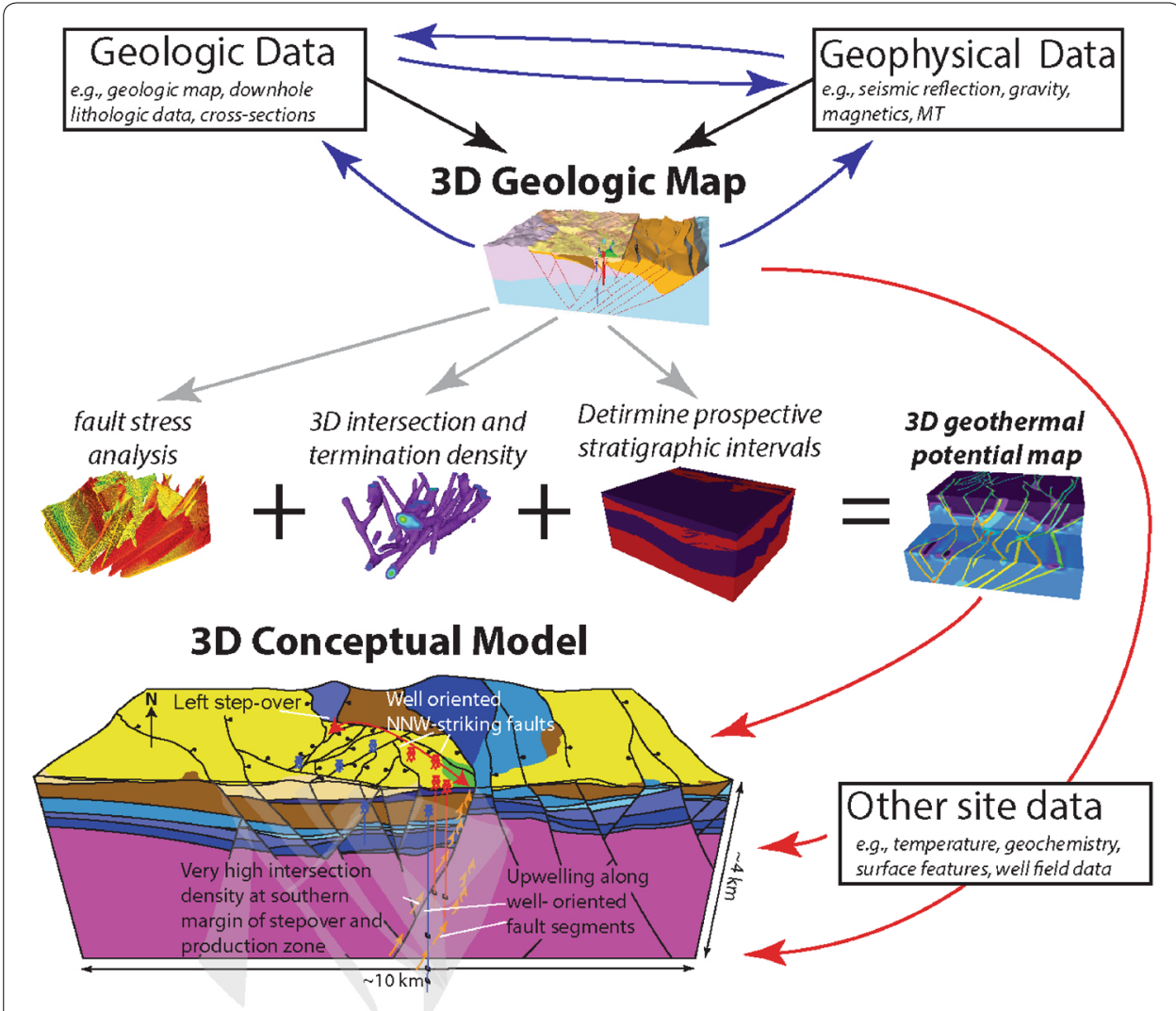

Fig. 3 Conceptual sketch illustrating the 3D geologic mapping and 3D geothermal potential mapping work flow. Geologic and geophysical data are integrated (black arrows) into a detailed 3D geologic map ("Methods: 3D geologic mapping"). Iteration of the interpretation between geologic and geophysical data, as well as between early versions of the 3D map and input data (blue arrows) is required to ensure that the 3D geologic map is consistent with all input data. The 3D geologic map is used to evaluate geothermal potential in 3D ("Methods: geothermal potential mapping"). 3D fault and stratigraphic surfaces are used to conduct fault stress analysis ("Fault stress state"), calculate the density of fault intersections and fault terminations ("Fault intersections and terminations"), and determine prospective stratigraphic intervals ("Host rock lithology"), gray arrows. These three maps are summed to produce the 3D geothermal potential map ("Evaluating geothermal potential in 3D"). To elucidate the specific highly prospective areas of the 3D geothermal potential map, geologic information from the 3D geologic map, and additional information about known areas of fluid flow from temperature or other data are integrated (red arrows) to build the 3D conceptual model of geothermal processes ("Results and discussion")

and stratigraphic framework local to a geothermal system with sufficient detail typically requires 1:24,000 scale or higher-resolution geologic mapping. This level of detail allows for delineation of faults and stratigraphy, geothermal deposits and alteration, and subtle structural features such as folds and complex fault interaction areas.

The 1:24,000 scale geologic map, cross sections and supporting data from the Tuscarora area (Dering 2013; Dering and Faulds 2013b) are available at https://gdr.openei.org/ submissions/357. The 1:24,000 scale geologic map, cross sections, and supporting data from the Neal Hot Springs area (Edwards and Faulds 2012; Edwards 2013) are available at https://gdr.openei.org/submissions/360. 


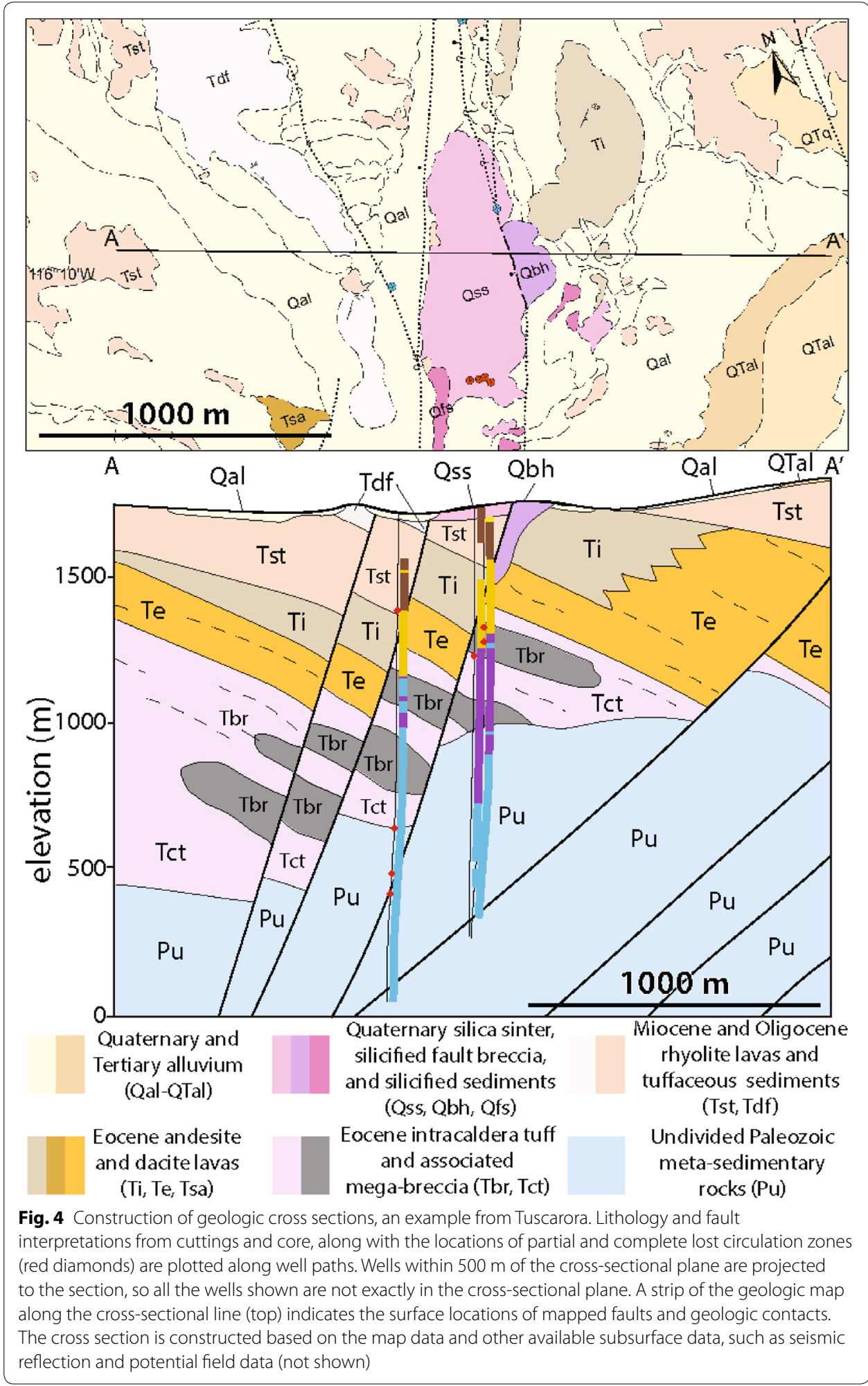

\section{Downhole data}

Data from boreholes provide key constraints on structure and stratigraphy at depth (e.g., Fig. 4). Lithologic analysis from core is the best constraint on subsurface stratigraphy, 
but detailed analyses of well cuttings (initial petrologic analysis using a binocular microscope and subsequent petrographic analysis of thin sections made from cuttings) can also provide reliable downhole lithologic constraints. It is crucial to interpret these data alongside geologic map and other subsurface data, such as any available seismic reflection or potential field data to ensure internal consistency of the interpretation.

Stratigraphic packages invariably contain multiple lithologies and are generally distinguished based on the dominant rock type(s) or by relative age. Isotopic age dating and/or whole rock geochemistry can be crucial in distinguishing stratigraphic packages that may appear homogenous in outcrop or in cuttings/core (Edwards and Faulds 2012; Edwards 2013). In our experience, lithologic interpretations from mud logs or driller logs can have highly variable quality and reliability. However, penetration rate data, downhole geophysical logs, and other data that are typically included with mud logs and other drilling data can be useful indicators of major lithologic changes and therefore help distinguish stratigraphic units.

Areas where circulation was lost during drilling and drilling breaks, both of which are typically noted on mud logs, are reliable indicators of major fractures and faults that may serve as geothermal fluid flow zones. Some large losses of circulation result in intermittent losses during the remainder of drilling. In this case, deep losses may actually be associated with loss zones at shallow levels. It is important, therefore, to interpret loss zone data along with geologic evidence for faulting, such as sections of shearing, clay gouge, or slickenlines identified in core or well cuttings, and the interpreted locations of faults from geophysical data. This ensures that the resultant structural model is consistent with all available data.

At Tuscarora, well cuttings and core from 12 wells were analyzed to construct the subsurface lithologic framework. Dering (2013) provided a full discussion of these data. At Neal Hot Springs, well cuttings and core from 24 wells were analyzed to construct the subsurface lithologic framework. Lithologic analysis of mafic volcanic units at Neal was aided by bulk rock geochemical data. Edwards (2013) furnished a full discussion of these data.

\section{Geophysical data}

A variety of geophysical datasets have proven to be useful in structural analysis of geothermal systems. 2D seismic reflection data can provide detailed information about fault structure (e.g., Louie et al. 2011; Queen et al. 2016). General basin shape, faults that control major topographic or structural relief, and the general dip/dip direction of strata, at the very least, are commonly interpretable. Discrete stratigraphic packages may be evident on seismic reflection profiles, especially at shallow levels above any volcanic material. Detailed stratigraphic information at deeper levels (especially, beneath thick volcanics), however, is not typically interpretable from reflection data. This is the result of complex velocity structure in highly faulted areas, high acoustic attenuation due to relatively thick volcanic sections, and/or low impedance contrasts within Cenozoic volcanic rocks or between the Cenozoic section and the pre-Cenozoic basement. Although steeply dipping faults may not be directly imaged, reflector discontinuity and lateral changes in reflection character can reliably indicate faults. Faults are easier to interpret 
at shallower levels, but they may need to be projected, with their specific locations at depth informed by downhole data or geophysical modeling.

With the limits of seismic reflection data at deeper levels, gravity and magnetic data are critical in constraining fault geometries and the contact between pre-Cenozoic basement and the Cenozoic section, especially in a blind geothermal area or in areas of generally poor bedrock exposure. Maximum horizontal gradients from gravity or magnetic data (e.g., Blakely 1996) can help to interpret fault structure, most notably faults with greater than hundreds of meters of offset (e.g., Blakely and Connard 1989), or where faulting juxtaposes stratigraphy with significant density or magnetic contrasts. 2D forward modeling of gravity and magnetic data, with well-constrained magnetic and density properties of the lithologic units, can also help to constrain structure, stratigraphy, and aid in cross-section construction (e.g., Talwani 1959; Geldart et al. 1966; Telford et al. 1990). Once a 3D geologic model is constructed, 2D or 3D inversion of potential field data (e.g., Witter et al. 2016) can be used to evaluate the misfit of the 3D geologic map relative to the potential field data.

Where available, magnetotelluric data and other tools that measure relative electrical resistivity/conductivity can be incorporated into the geologic interpretation. High conductivity $<10 \Omega-\mathrm{m}$ ) in 2D or 3D MT inversions can be caused by circulating fluids and intense smectite clay alteration, indicating the presence of the 'clay cap' a diagnostic feature of some geothermal reservoirs (Uchida and Sasaki 2006; Cumming and Mackie 2007; Newman et al. 2008; Peacock et al. 2012; Munoz 2014). High conductivities and abundant clays are also common in many basin sedimentary sequences and are not related to geothermal processes. As a result, care must be taken in interpretation of conductivity data, since relatively high electrical conductivity does not necessarily always correlate with modern fluid circulation systems.

In regards to the present study, regional gravity data constrain the general shape and extent of the Independence Valley basin in which Tuscarora lies (Dering 2013). A combination of seismic reflection data, detailed gravity gradient data, and 2D forward modeling of gravity help to constrain the subsurface structure at Neal Hot Springs (Colwell 2013; Edwards 2013).

\section{D geologic cross sections}

2D geologic cross sections are a crucial component of interpreting geothermal fieldscale geologic structure. Construction of 2D geologic cross sections requires synthesis of all available data: seismic reflection and other geophysical data, downhole lithologic data, and geologic map data. 2D cross-sectional profiles are generally selected orthogonal to the structural grain, but along-strike profiles are also important to constrain along-strike structural variation. Enough profiles need to be constructed to characterize $3 \mathrm{D}$ variations in geologic structure at a scale that is appropriate for the available data. Well paths, typically those within a few hundred meters of the cross-section profiles are projected to nearby profiles to aid cross-section construction (e.g., Fig. 4). Shorter projection distances are better, but the appropriate distance depends on the complexity of the geology and the density of the data.

Iterative revision of mapped fault traces and cross sections is required. Downhole lithologic data and the interpreted locations of surface fault traces guide seismic reflection 


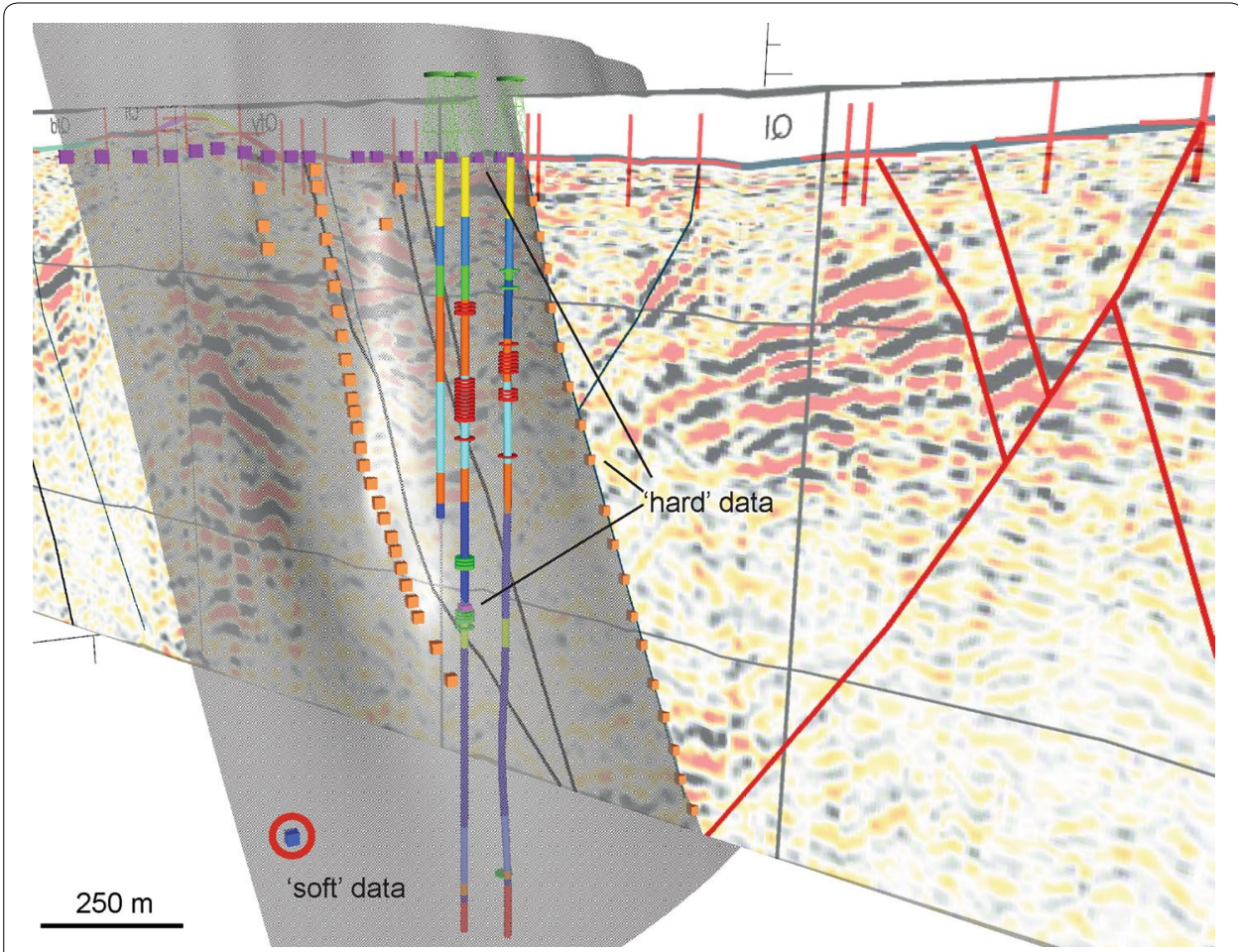

Fig. 5 3D fault mapping. This example shows the process of interpreting and digitizing one fault from Astor Pass (Siler et al. 2016a). Seismic reflection interpretation (orange cubes), the occurrence of fault gouge/ slickenlines in cuttings, losses of circulation during drilling (green and red discs on the well paths), and geologic map data (purple cubes at the surface) are 'hard' data that control the geometry of the 3D fault surface (gray, transparent). 'Soft' data (blue cube) constrains the fault geometry distal to the hard data, such that strike and dip remain consistent with the hard data along the entire length of the fault

interpretation, potential field modeling, and construction of cross sections (Fig. 4). Conversely, seismic reflection data and potential field modeling are used to clarify uncertainties in the structural interpretation made from lithologic logs. Mapped surface fault traces and faults interpreted from the subsurface data are correlated, and faults evident in subsurface data but unexposed or obscured at the surface are added to the 2D map. Along-strike correlation between multiple across-strike cross sections is critical. Potential field anomalies and horizontal potential field gradients are interpreted to aid in along-strike fault correlations. Faults spanning multiple across-strike cross sections are noted, so that the along-strike variation in fault offset and fault dip are internally consistent. We have found that importing cross sections into 3D space is an efficient method to correlate fault geometry and offset along strike. Subsequently, the 2D cross sections are modified and re-projected in 3D space for additional quality control.

Five geologic cross sections were drawn at Tuscarora incorporating 1:24,000 scale geologic map data, downhole lithologic data, and regional gravity anomalies (Dering 2013). Three geologic cross sections at Neal Hot Springs were drawn incorporating 1:24,000 scale geologic map data, downhole lithologic data, seismic reflection interpretation, gravity gradients, and gravity modeling (Edwards 2013). 


\section{D geologic mapping}

Once the geologic and geophysical interpretations are completed, the 2D geologic map, 2D geologic cross sections, and other appropriate data are imported into the 3D software framework (Fig. 5). Many commercial software packages can be utilized, and the methods described herein are not unique to any particular software. The methodology detailed below is similar to, and builds upon, other recent contributions (Moeck et al. 2009a, b, 2010; Jolie et al. 2012, 2015b; Siler et al. 2016a). In building a 3D geologic map, it is useful to have one or more working conceptual models. This helps to avoid a number of cognitive biases that can affect geologic interpretation (Krueger and Funder 2004; Bond 2015). Working conceptual models can be tested and updated (or dismissed) as the 3D interpretation is refined (Bond 2015).

\section{Building the fault map}

Development of a 3D fault map begins with digitization of fault traces from the 2D geologic map, digitizing fault profiles from $2 \mathrm{D}$ cross sections, and digitizing fault interpretations from subsurface well data (or importing these from a geographic information system).

It is important to note that 3D geologic surfaces that are calculated in geoscience software can take on unrealistic geometries where data are sparse or absent. To constrain a surface in an area distal to the data, it may be necessary to use additional control. We distinguish between 'hard' data (data from the geologic map, 2D cross sections, and downhole data) and 'soft' data (points that are added to constrain the calculated surfaces where hard data are not sufficient to calculate geologically realistic geometries). Though geologic maps, geophysical interpretations, cross sections, and downhole lithologic information are all interpretive to some degree (e.g., Bond et al. 2007; Bond 2015), for our purposes they constitute the baseline geologic information and are treated as 'hard' data.

'Soft' data are added to continue structural geometries that are defined by the conceptual model(s) and 'hard' data, such that basic geologic principles (which are part of the conceptual model) are not violated (e.g., Fig. 5). If, for example, cross-section data indicate that a fault has a listric geometry at depth (a working conceptual model of the structural geometry), 'soft' data are needed to retain the progressive change in dip with depth so that it is consistent along the full strike length of a fault. As building of the 3D fault map progresses and cross sections, the geologic map, etc. are iteratively adjusted, the conceptual model may need to be adjusted, and 'soft' data are adjusted accordingly.

\section{Building the 3D stratigraphic map}

Development of a 3D stratigraphic map begins with digitization of stratigraphic contacts (or importing these from a geographic information system), as defined on 2D cross sections, downhole data, lithologic logs, and the geologic map. Stratigraphic contacts on the geologic map are treated as 'hard' data and control formulation of a conceptual model of the stratigraphy. A key aspect of 3D mapping in geothermal fields is our ability to incorporate complex geologic variation into the 3D map. For example, volcano-stratigraphic units, which are present in the Basin and Range and in many geothermal fields 


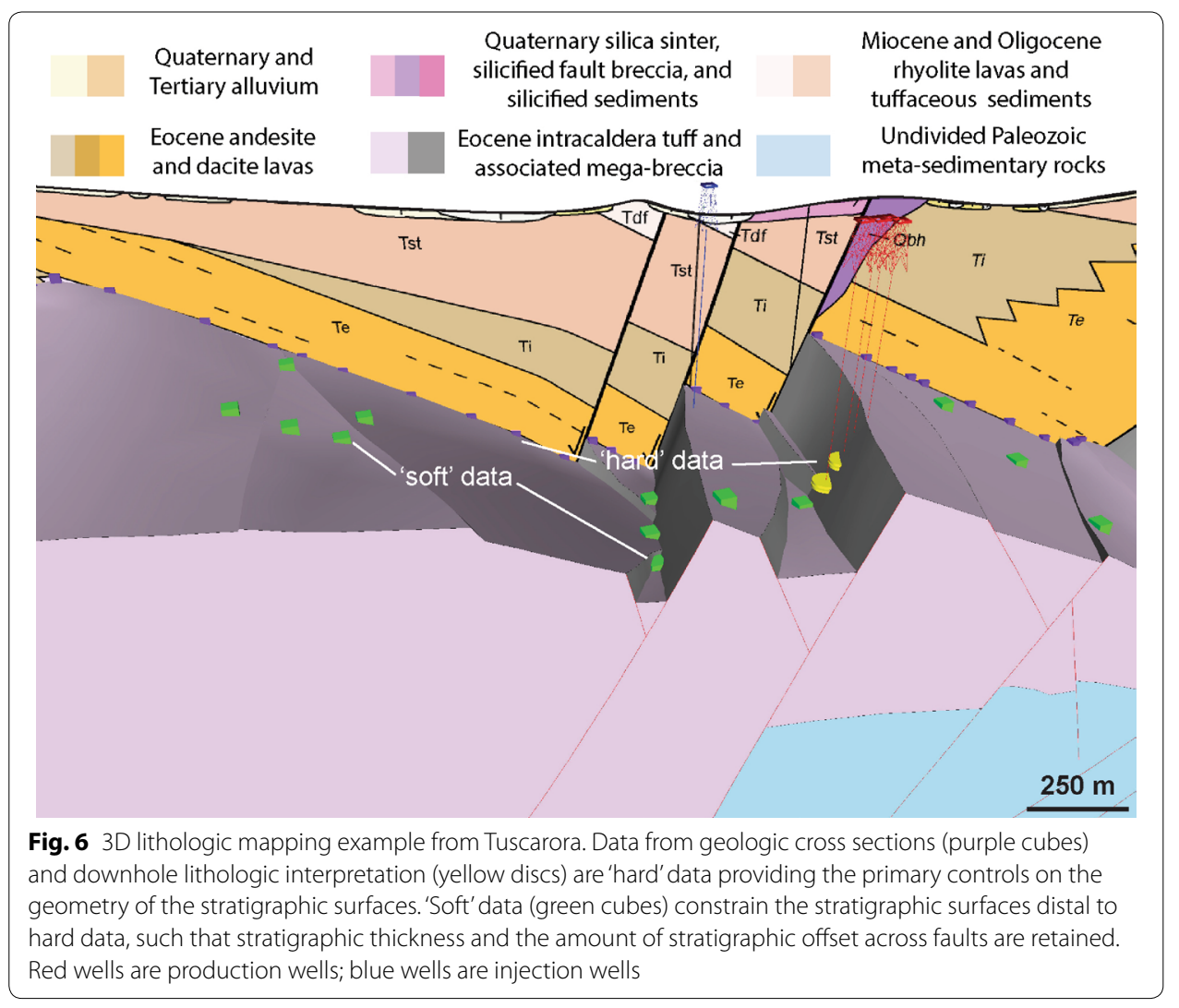

worldwide, can have significant lateral thickness variations. Ash-flow tuffs typically have large areal extent but are subject to local thickness changes, pinch outs, and channelization controlled by paleotopography (e.g., Henry and Faulds 2010). This can also be the case with mafic lava flows. Dacite and rhyolite flows, on the other hand, typically have limited areal extent as a result of their high eruptive viscosity. Any evident discontinuity in the thicknesses or extent of these more felsic lava flows may be associated with their relatively small areal coverage or truncation due to faulting, rather than channelization. Sedimentary deposits are also likely to be channelized or confined to local basins. Soft data may be needed to retain the strike and dip of stratigraphic units, the thickness of stratigraphic units, and the stratigraphic offset across faults (e.g., Fig. 6) and to continue trends in the change in strike, dip, thickness, or fault offset indicated by the input data and conceptual models of the stratigraphic unit geometries as explained above.

\section{Assessing uncertainty in 3D geologic maps}

There is an inherent problem of incomplete knowledge of the subsurface in any $3 \mathrm{D}$ geologic interpretation. Each input dataset has its own objective (i.e., quantifiable) uncertainties related to data acquisition and processing. These uncertainties are probably small relative to the uncertainty in the interpretational space, which corresponds to the area that lies between points of 'hard' input data where extrapolation is required (e.g., Bond et al. 2007). As a result, 3D geologic maps, which display discrete planes (faults, 


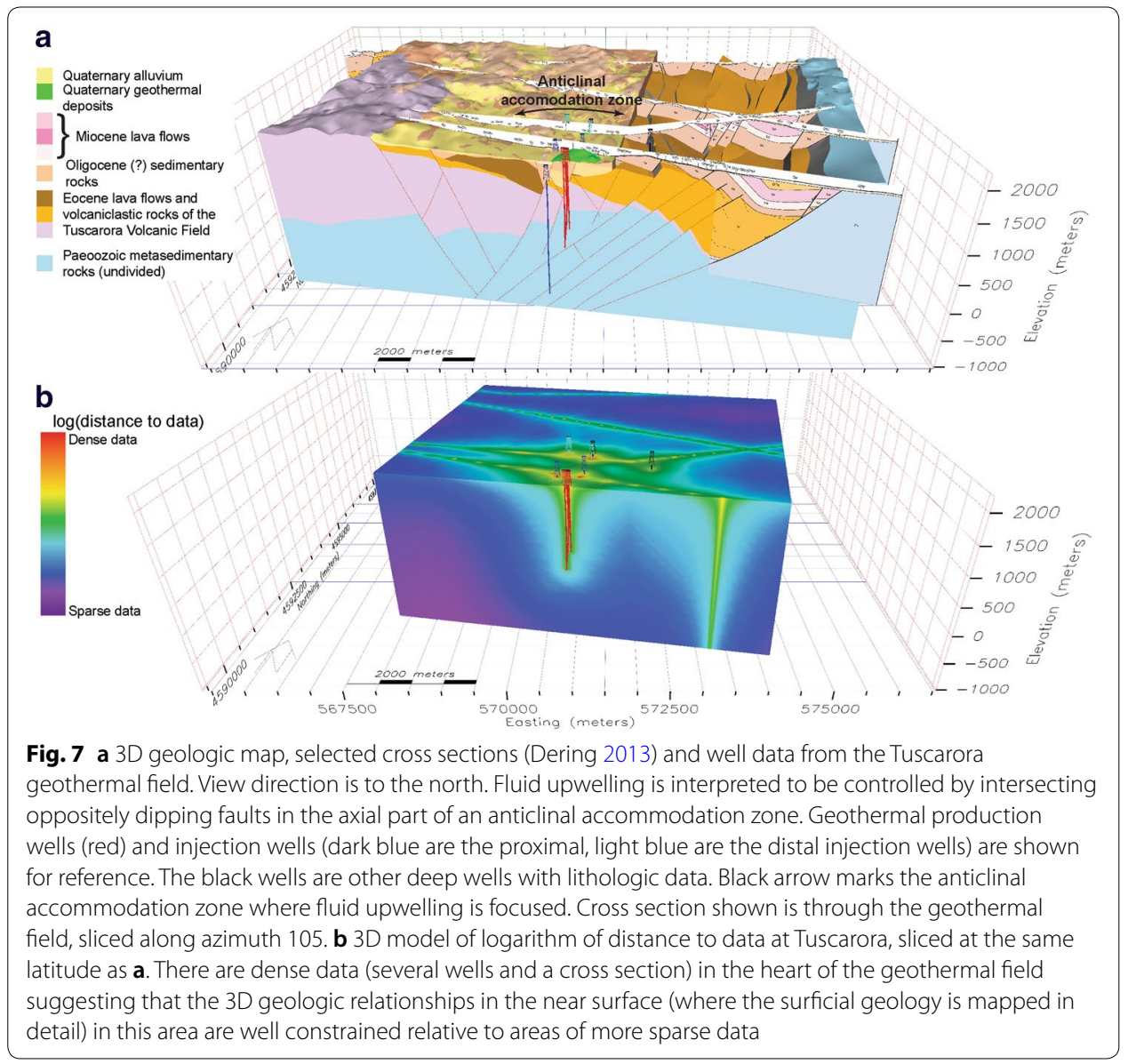

stratigraphic contacts) and volumes in the subsurface, may appear to be more certain than they are in actuality. In cases in which there are subsequent analyses based on the 3D map data, as we present below, it is critical to document (at least in a relative sense) where the displayed geologic relationships are well constrained by data and where they are not. Bond (2015) emphasized the importance of visualizing geologic uncertainty. Along these lines we calculate the 3D density of data used in construction of the Tuscarora and Neal Hot Spring 3D maps. The distance from well data, surficially derived geophysical and 2D map data, and 2D geologic cross sections is calculated throughout each 3D map. The summed distance to data (Figs. 7b, 8b) indicates which areas of the 3D map are well constrained by data and in which areas the geologic relationships have relatively higher uncertainty.

\section{D geologic mapping results}

\section{Tuscarora}

The Tuscarora geothermal system lies at the northern end of Independence Valley, an east-tilted half graben in the northern Basin and Range province, north-northeast of Elko, Nevada (Fig. 1). Neogene basin-fill sediments and underlying Tertiary volcanic and Paleozoic sedimentary bedrock dip toward a system of large, west-dipping normal faults that bound the east side of the basin and extend $\sim 120 \mathrm{~km}$ along strike. These 


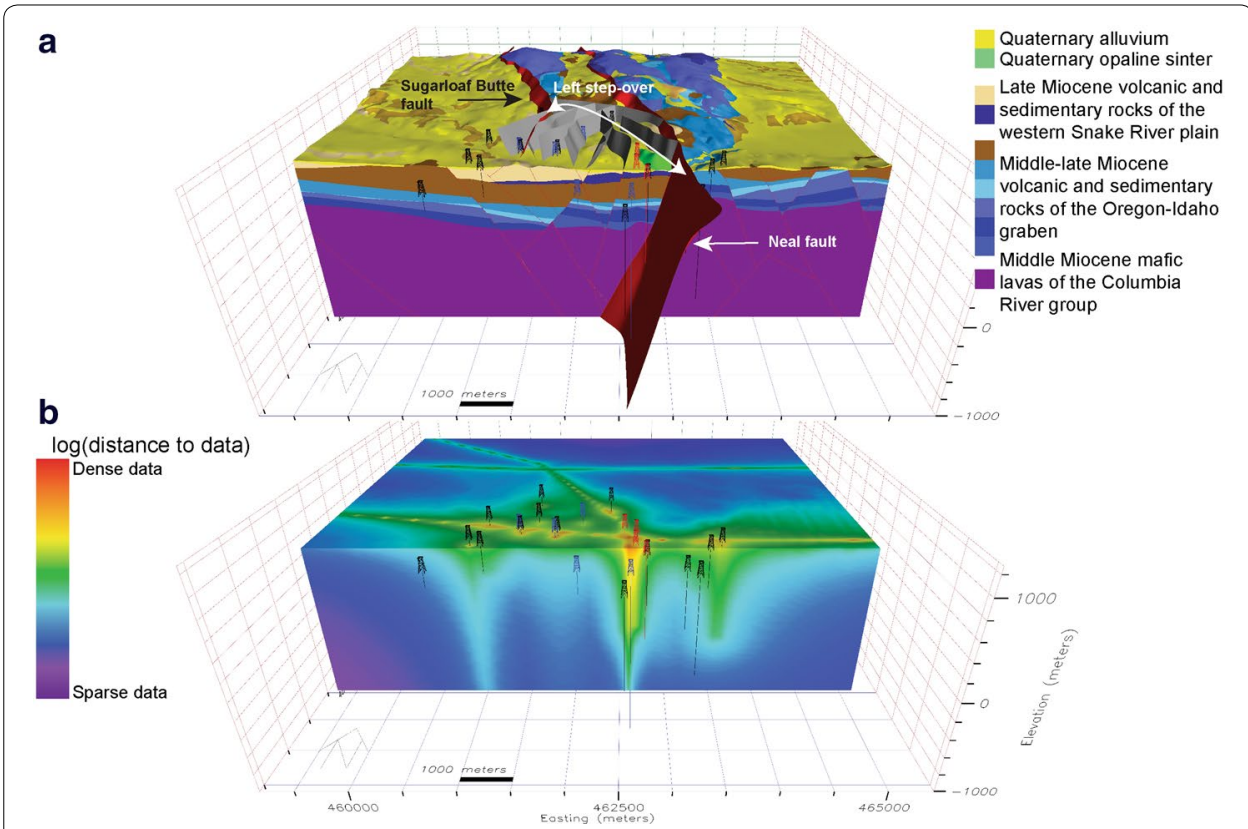

Fig. 8 a 3D geologic map of the Neal Hot Springs geothermal field. View direction is to the north. Quaternary opaline silica sinter is show in green. Fluid upwelling (red wells are production wells) is interpreted to be controlled by a left step-over (or relay ramp) between two west-dipping normal faults, the Neal fault to the east and the Sugarloaf Butte fault to the west (both in red), and the associated high-density faulting within the step-over (gray faults). b 3D model of logarithm of distance to input data (lithologic data along wells, surficial geophysical and 2D geologic map data, and 2D geologic cross sections and seismic reflection profiles) to the Neal model. Cross section shown, sliced east-west though the geothermal field is the same as a. High data density in the Neal step-over suggests that the 3D geologic relationships in this area are well constrained relative to areas of sparse data

west-dipping normal faults have accommodated several kilometers of displacement and are the primary control on the basin geometry. A secondary system of east-dipping normal faults in the central to western parts of Independence Valley overlaps the westdipping fault system to form a several-kilometer-wide anticlinal accommodation zone (Dering 2013; Dering and Faulds 2013a, b; Fig. 7a). Field measurements define the dips of both fault systems, but in locations of sparse exposure, dip values have been used that adhere to the principles of rock mechanics and that are compatible with the geometry of the observed tilted fault blocks. The geothermal system lies in the axial part of the accommodation zone.

Within the accommodation zone, a series of boiling springs and fossil sinter terraces lie along the trace of a northerly striking, west-dipping normal fault. Evidence of geothermal outflow extends $2 \mathrm{~km}$ along the fault trace, but active springs are concentrated at the northern termination of the fault. The geothermal upwelling appears to be focused within a dense network of small, overlapping normal faults, restricted to a corridor less than $500 \mathrm{~m}$ wide along the axial part of the anticline, where the dominant polarity of the faults shifts from east to west dipping (Fig. 7a). A single north-northeast-striking, west-dipping normal fault within this narrow zone supplies the production wells associated with a 24 MWe capacity power plant constructed in 2012 (Dering 2013; Dering and Faulds 2013b). The geothermal fluids are extracted from limestones and claystones that 
dominate the Paleozoic basement stratigraphy of the region. The relatively high density of data from wells in the narrow axial part of the accommodation zone suggests relatively high confidence in the 3D geologic relationships in this area relative to the periphery of the 3D map where subsurface data are sparser (Fig. 7b).

\section{Neal Hot Springs}

The Neal Hot Springs geothermal system lies $\sim 25 \mathrm{~km}$ west of Vale, Oregon, between the Miocene Oregon-Idaho graben to the west and the Miocene to present western Snake River Plain to the east (Fig. 1). Geothermal fluids effuse from opaline sinter mounds along the Neal fault. The geothermal system at Neal supports a $22 \mathrm{MWe}$ capacity power station, which has been in operation since 2012, with four wells producing $\sim 141{ }^{\circ} \mathrm{C}$ geothermal fluids at $715 \mathrm{~kg} / \mathrm{s}$ (Warren 2016). Geologic mapping at 1:24,000 scale, interpretation of four seismic reflection profiles, 2D gravity data modeling, and interpretation of lithologic data from core and cuttings from 24 wells were carried out to analyze the structural controls on geothermal upwelling at Neal Hot Springs (Edwards and Faulds 2012; Colwell 2013; Edwards 2013).

The Neal area is characterized by Miocene-Pliocene volcanic and sedimentary rocks cut by a system of primarily west-dipping normal faults. The Tertiary section nonconformably overlies Mesozoic granitic and metamorphic basement (Edwards and Faulds 2012; Edwards 2013). The structural and lithologic characteristics of the Mesozoic section are not well constrained. Thus, only the Miocene and younger section was included in the 3D map (Fig. 8). Detailed geologic mapping shows that gently east-dipping fault blocks consist of interlayered middle Miocene basaltic lava flows of the Columbia River Group overlain by middle-late Miocene basaltic and rhyolitic lava flows, lacustrine and fluvial sedimentary rocks, and ash-flow and ash-fall tuffs. The Miocene strata are overlain by Quaternary alluvial deposits. The section is cut by both west- and east-dipping, north- to northwest-striking normal faults.

A hard-linked, complexly faulted left step-over (or relay ramp) between two overlapping west-dipping normal fault zones, the Neal fault to the east and the Sugarloaf Butte fault to the west (Fig. 8), controls fluid upwelling to the surface (Edwards and Faulds 2012; Edwards 2013). The four production wells produce geothermal fluid from the Neal fault in fractured basaltic lavas at depths between 700 and $1100 \mathrm{~m}$ along $\sim 1 \mathrm{~km}$ strike near the southeastern corner of the step-over. This production zone is partially capped by a rhyolitic tuff, which is altered to varying degrees and prevents most of the geothermal fluids from making it to the surface. The relatively high density of data from wells and 2D reflection profiles within the step-over and especially local to the Neal fault suggests relatively high confidence in the 3D geologic relationship in this area relative to the periphery of the 3D map where subsurface data are sparser (Fig. 7b).

\section{Methods: geothermal potential mapping}

3D geologic maps (Figs. 7, 8) can be used for a number of different applications (e.g., Jachens et al. 2001; Phelps et al. 2008; Moeck et al. 2009a). Here, we use the 3D geologic map data to delineate the geothermal potential in 3D. Fault segments that are critically stressed and structural discontinuities (e.g., fault intersections or terminations) are 
typically associated with relatively high density fracture networks and have been shown to be important fluid flow conduits (Sibson 1996; Zoback and Townend 2001). The competency of lithologies that host fault zones is also an important control on the development of fracture permeability (Norton and Knapp 1977; Brace 1980; Sibson 1996). These geologic proxies are used to evaluate the potential for fault-controlled permeability throughout the 3D geologic map (Fig. 3). The spatial correspondence between the fracture permeability potential, evidence for elevated temperatures, and any evidence for geothermal fluids are used to evaluate the potential for geothermal upwelling throughout the 3D map area (Siler and Faulds 2013b).

We use a cellular-based approach, whereby each cell has an associated rock type, is classified by whether or not it is associated with a fault, and has calculated values for fault stress state and fault intersection and termination density. The cell size used is selected such that the appropriate spatial resolution can be achieved (here, we investigate the geologic variation at the tens of meters scale). The overall number of cells, however, is limited by computing power. The Neal Hot Springs and Tuscarora 3D geothermal potential maps have $15 \mathrm{~m}$ cell sizes.

\section{Geothermal permeability proxies Fault zones}

A fault damage zone, representing the effective width of fracturing and permeability enhancement associated with faulting, is generated for each fault plane in the 3D geologic map. In a complexly faulted area like many structurally controlled geothermal fields, fault zone width and geologic character are expected to be non-uniform, depending on fault length, displacement, rock type, and other characteristics (Cowie and Scholz 1992; Scholz et al. 1993; Anders and Wiltschko 1994). Fault zone widths can be defined based on the observed fault zone widths in the field or in well logs, if these data are available. Alternatively, published scaling relationships provide rough estimates of the effective width of permeability in fault zones. These relationships suggest that, for example, the damage zone width of a $10 \mathrm{~km}$-long fault zone with $100 \mathrm{~m}$ of displacement can range from 10 to $1000 \mathrm{~m}$ (Scholz et al. 1993; Anders and Wiltschko 1994). Ultimately, we typically construct fault zones that are $\sim 10$ s of meters wide. This is consistent with both the scaling relationships noted above for faults with kilometer-scale length and with the thickness of flowing intervals reported in geothermal wells in the western USA, which are in the order of a few tens of meters wide or smaller (based on review of publicly available well data from the Nevada Division of Minerals).

Because our methodology is focused on structurally controlled geothermal systems, we assume that all fault zones in the 3D geologic map have the potential to act as fluid upwelling zones and that all areas outside of fault zones have no potential to act as fluid upwelling zones. Both of these assumptions are inherently flawed. Many geologic formations can have abundant matrix or fracture permeability and may serve as stratigraphic reservoirs. Additionally, fluid upwelling in geothermal fields is generally spatially discrete (e.g., Caine et al. 1996, 2010; Caine and Forster 1999; Fairley et al. 2003; Fairley and Hinds 2004; Mitchell and Faulkner 2012; Meller and Kohl 2014), which means that most segments along faults are impermeable to upflow. This may be a function of the generation of clay gouge during faulting or hydrothermal mineralization, both of which can 
seal faults. However, in the structurally controlled geothermal systems evaluated here, the most prominent geothermal upwellings occur along fault zones (e.g., Richards and Blackwell 2002). By assuming that only faults conduct fluid upwelling and that the whole fault system has the potential to host upflow, we can evaluate which geologic factors are most highly coincident with known upwelling zones. The calculated potential for upwelling within each fault segment can be enhanced relative to other fault segments by any or all of the three following proxies for permeability: (1) the stress state of the fault, (2) location of that fault relative to structural discontinuities, and (3) host rock lithology.

\section{Fault stress state}

The degree to which a fault zone is stressed is an indicator of the potential of that fault to act as a conduit for fluid flow. Faults subject to conditions close to failure are described as critically stressed and are conducive to fluid flow. (Sibson 1994, 1996; Barton et al. 1995; Morris et al. 1996; Ito and Zoback 2000; Townend and Zoback 2000; Zoback and Townend 2001; Micklethwaite et al. 2015). The stress state of faults can be described in terms of slip tendency (Morris et al. 1996) and dilation tendency (Ferrill et al. 1999). These are quantitative indicators of the resolved shear and normal stresses on faults and therefore allow evaluation of the relative variation in stress state along a single fault and between individual faults. An important caveat is that slip and dilation tendencies do not incorporate frictional fault strength and therefore do not indicate the complete stress state of a fault. In the tectonically active western USA, we assume that most Neogene faults will be relatively near a critically stressed state, such that slip and dilation tendencies serve as appropriate proxies for the stress state as it pertains to the fluid flow potential of a fault.

Analyses of drilling-induced fractures and extended leak-off tests/mini frack tests in boreholes (Peška and Zoback 1995; Zoback et al. 2003) provide the most reliable information about the magnitudes and orientation of the modern stress field. However, stress variation within geothermal fields and with depth within individual boreholes are well documented (Hickman et al. 1998; Blake and Davatzes 2011), so comparison of stress results from well data to stress orientations calculated based on local earthquake focal mechanisms or other local stress data ensures that the applied stress field is appropriate. Stress orientations and magnitudes calculated through inversion of fault kinematic data can also be useful (Hinz et al. 2014; Jolie et al. 2015b). These measurements should be interpreted within a local and regional context and compared with other local stress data to ensure that they are representative of the modern stress conditions, rather than an average of the stress conditions that have driven multiple generations of faulting.

Slip and dilation tendencies are calculated for each 3D fault plane based on the ambient stress conditions in the geothermal field. Each fault zone is populated with the slip and dilation tendency values from the appropriate fault plane, resulting in 3D maps both for slip tendency and dilation tendency (Figs. 9, 10). A consequence of 3D fault mapping is that fault surfaces are typically progressively smoother with increasing depth as a result of increasing in distance from the surficial input data. Slip and dilation tendency values therefore will be more variable near the surface than at depth. This increased smoothing with distance from the surface must be accounted for in the final interpretation of geothermal processes. 


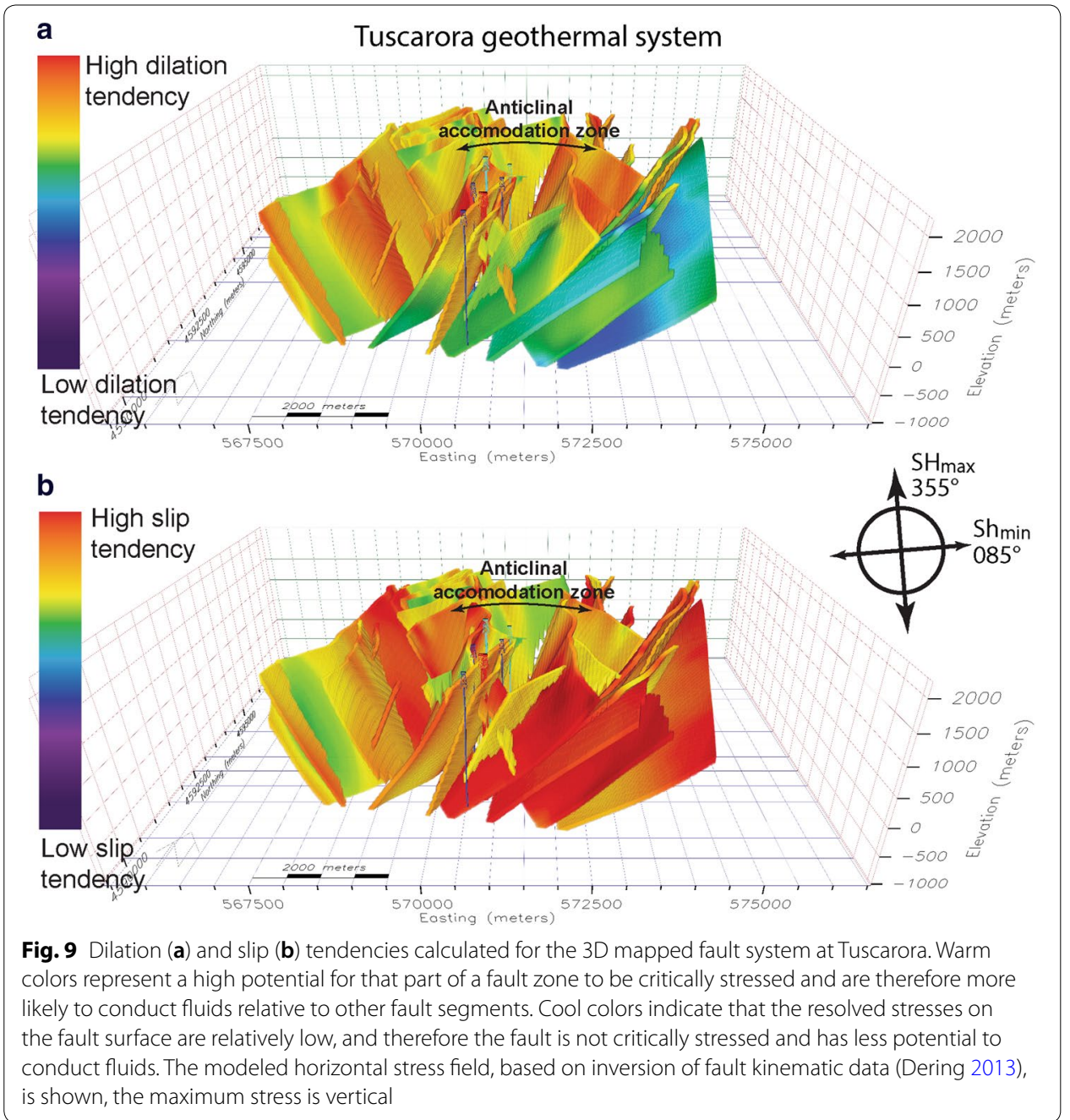

At Tuscarora, inversion of fault kinematic data suggests that the minimum horizontal compressive stress $\left(S_{\mathrm{hmin}}\right)$ is oriented $085^{\circ}$ in a normal faulting stress regime $\left(S_{\mathrm{v}}>S_{\mathrm{hmax}}>S_{\mathrm{hmin}}\right.$; the magnitude of the vertical stress is larger than the magnitude of the maximum horizontal stress, which is larger than the magnitude of minimum horizontal stress), though this likely represents an average of the stress conditions since the middle Miocene (Dering 2013). We applied a representative Basin and Range stress field, with $S_{\mathrm{hmin}} / S_{\mathrm{v}}=0.62$, as calculated at Astor Pass and Dixie Valley, Nevada (Hickman et al. 1998; Siler et al. 2016a), and $S_{\mathrm{h} \max }=\left(S_{\mathrm{hmin}}+S_{\mathrm{v}}\right) / 2$, as suggested at Desert Peak, Nevada (Hickman and Davatzes 2010). All stress magnitudes are assumed to increase linearly with depth. Under these stress conditions steeply dipping north-striking faults have the highest dilation tendency, whereas slip tendency is maximized along moderately dipping north-striking faults (Fig. 9).

Inversion of fault kinematic data suggests that the Neal Hot Springs area is characterized by a minimum horizontal compressive stress $\left(S_{\mathrm{hmin}}\right)$ oriented $063^{\circ}$ and a normal faulting stress regime $\left(S_{\mathrm{v}}>S_{\mathrm{hmax}}>S_{\mathrm{hmin}}\right)$. As above, a representative stress field was used, with $S_{\mathrm{hmin}} / S_{\mathrm{v}}=0.62$ and $S_{\mathrm{hmax}}=\left(S_{\mathrm{hmin}}+S_{\mathrm{v}}\right) / 2$. All stress magnitudes increase linearly 


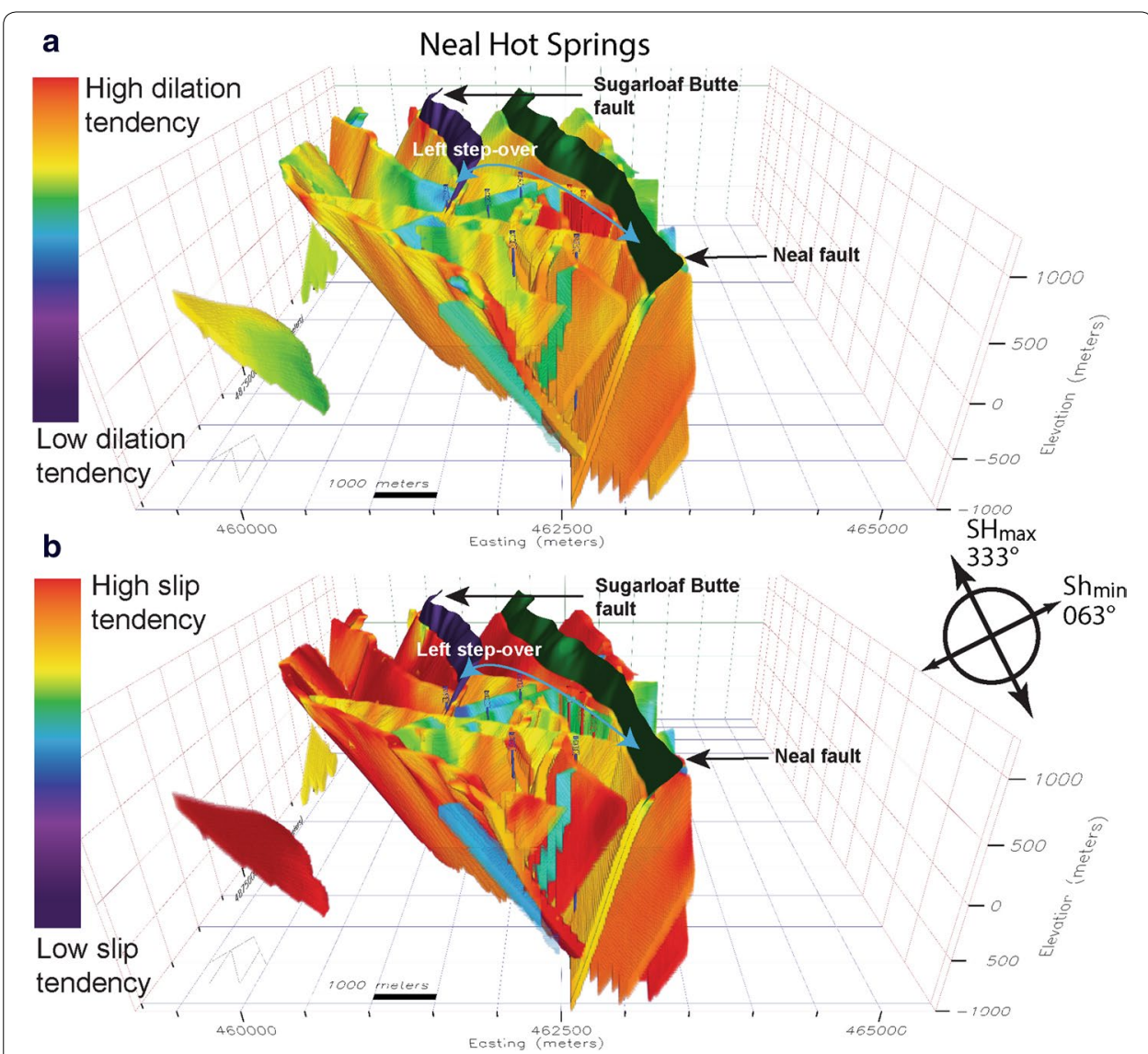

Fig. 10 Dilation (a) and slip (b) tendencies calculated for the 3D mapped fault system at Neal Hot Springs. Warm colors represent a high potential for that part of a fault zone to be critically stressed and are therefore more likely to conduct fluids relative to other fault segments. Cool colors indicate that the resolved stresses on the fault surface are relatively low, and therefore the fault is not critically stressed and has less potential to conduct fluids. The modeled horizontal stress field, based on inversion of fault kinematic data, is shown; the maximum stress is vertical

with depth. Under these stress conditions north-northwest-striking and moderately dipping faults have the highest slip tendency, whereas north-northwest-striking, steeply dipping faults have the highest dilation tendency (Fig. 10).

\section{Fault intersections and terminations}

Tectonic stresses are concentrated at discontinuities along faults (Pollard and Aydin 1988; Scholz et al. 1993). This results in a relatively high density of secondary faults and fractures, as well as high fracture permeability. These areas are known to host fluid flow (Curewitz and Karson 1997, 1998; Micklethwaite and Cox 2004; Faulds et al. 2006, 2011, 2013; Sheldon and Micklethwaite 2007; Faulds and Hinz 2015; Siler et al. 2018). Fault intersections and fault terminations are two types of discontinuities that are associated with dense faulting, fracturing, and with many geothermal occurrences in the western US and around the world (Faulds et al. 2006, 2011; Faulds and Hinz 2015).

Within the 3D geologic map, fault intersections and fault terminations are spatially registered, and the density of intersections and terminations per unit area can 


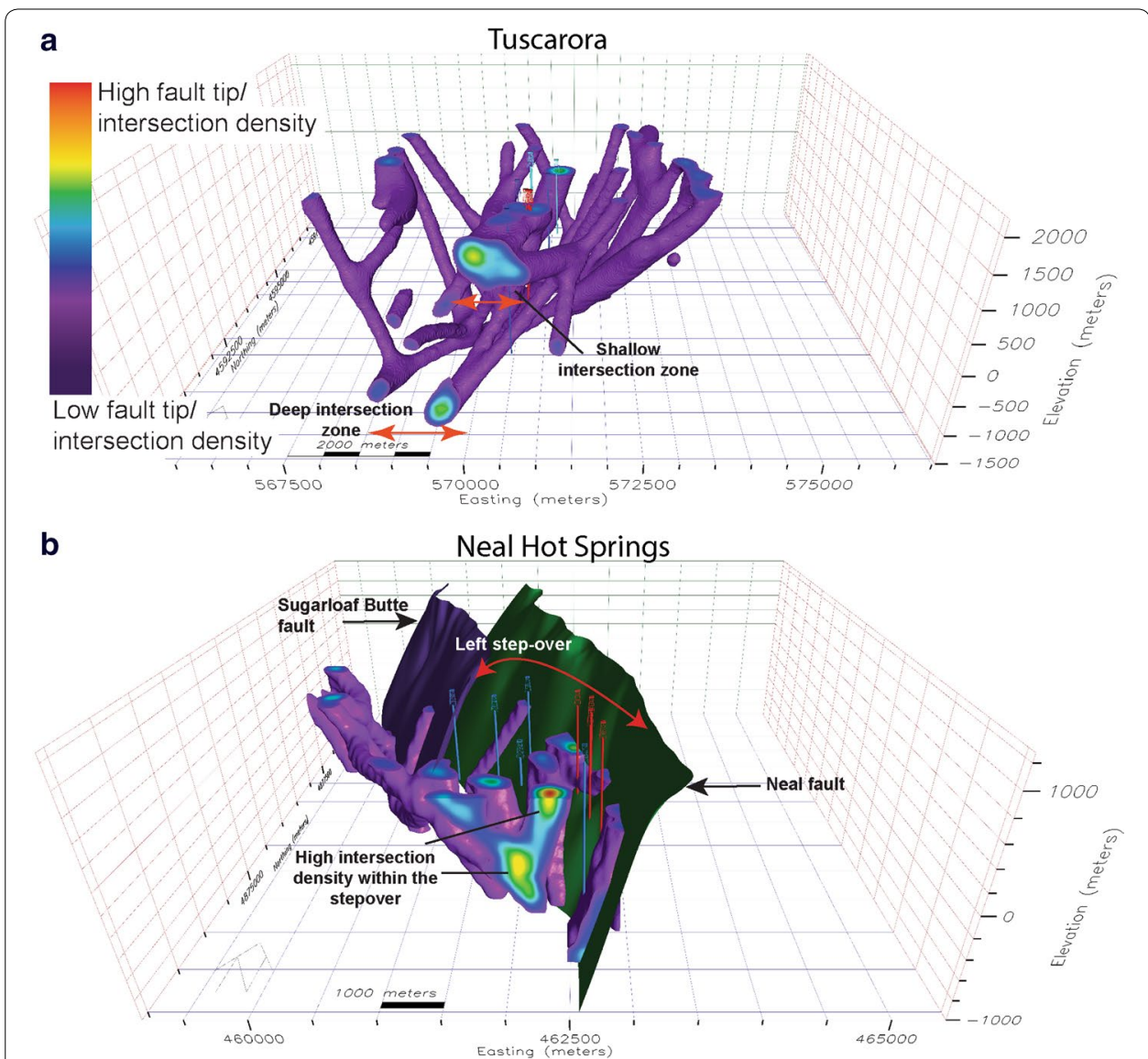

Fig. 11 Calculated density of fault intersections and fault tips in a the Tuscarora area, and $\mathbf{b}$ the Neal Hot Springs area. Warm colors represent a high spatial density of fault intersections and fault terminations. In these locations there is a relatively higher likelihood for dense, interconnected fracture networks, as well as a relatively high potential for geothermal fluid flow. The isolated columns indicate the intersection of two faults or one fault termination. Larger volumes correspond to progressively higher fault intersection/termination densities. a At Tuscarora within the accommodation zone there are two sub-horizontal areas of relatively high intersection density at $\sim 1200 \mathrm{~m}$ elevation ( $3000 \mathrm{~m}$ depth) and at $\sim 600 \mathrm{~m}$ elevation ( 1200 m depth). b At Neal Hot Springs, the highest intersection density occurs within the step-over between The Neal fault (right) and Sugarloaf Butte fault (left)

be calculated in 3D space, following the method of Alberti (2011). A 'breakdown region, the area proximal to a fault termination where fracture density is highest, is proportional to $10^{-2}$ times the half-length of the fault (Pollard and Aydin 1988; Scholz et al. 1993). In this way, the volume of fault intersection/termination regions scales with the length of the surface trace of the faults in the 3D map. Single fault intersections or terminations are represented by columns with high intersection/termination density in the center of the column and intersection/termination density decreasing linearly to zero at the edge. Areas of fault intersections and terminations with higher density are represented by larger, irregular volumes with fault intersection/termination density values decreasing linearly to zero at the edges (Fig. 11).

At Tuscarora, there are two dense areas of fault intersections between oppositely dipping faults and fault terminations in the axial part of the anticlinal accommodation zone. The deeper zone lies at $\sim 3000 \mathrm{~m}$ depth and the shallower at $\sim 1200 \mathrm{~m}$ 
depth (Fig. 11a). At Neal Hot Springs the densest area of fault intersections occupies the southeastern margin of the step-over due to a dense network of fault intersections between the Neal fault and Sugarloaf Butte fault in the step-over (Fig. 11b).

\section{Host rock lithology}

Relatively weak lithologic units (e.g., shales or unconsolidated sediments) do not support dense, interconnected, fault and fracture networks to the same degree as more competent units (Norton and Knapp 1977; Brace 1980; Sibson 1996). Where cut by fault zones, weak lithologies are less likely to host interconnected fault and fracture networks. In highly fractured or fragmental volcanic rocks, such as glassy tuffs and volcaniclastics, alteration of glass and feldspars to clays occurs prominently at geothermal temperatures. These lithologies may be weaker when faulted relative to devitrified tuffs, igneous rocks, and lava flows.

A variety of other datasets can be used as a proxy for the favorability of each stratigraphic unit to host fracture permeability and fluid flow. Pressure-temperature-spinner logs, for example, may reveal discrete flowing intervals in wells correlated to specific faults or lithologic intervals in the 3D geologic map. This type of information may also be available on mud logs or well completion reports. Well construction reports (detailing depth of the casing 'shoe', above which the well has been cemented with steel casing and therefore sealed off from the formation) can also provide information relevant to which lithologic intervals tend to host permeability intervals. In a productive geothermal field, intervals along production or injection wells that are cased with slotted liners, otherwise open to fluid flow, and/or correspond with fault zones can be interpreted within lithologies favorable for hosting permeability and fluid flow. If flowing intervals are not faulted, geothermal fluids may reside with primary stratigraphic permeability that is charged with upwelling fluids from nearby faults (Siler et al. 2016a).

At Tuscarora, geothermal production and mud log data suggest that flowing zones and open fractures occur primarily within the Paleozoic metasedimentary section (Chabora et al. 2015), so we conclude that fault zones cutting this section have a higher likelihood of conducting geothermal upwelling than faults cutting the overlying Cenozoic volcanic and sedimentary sections. At Neal Hot Springs, geothermal production exclusively occurs from the middle Miocene mafic lava flows of the Columbia River Group (Edwards and Faulds 2012; Edwards 2013; Warren 2016). We infer, therefore, that the Columbia River Group section has a higher potential to host fluid upwelling relative to the overlying volcanic and sedimentary sections.

\section{Temperature and fluids}

Temperature data are both direct indicators of anomalous heat and proxies for circulating fluids. Temperature anomalies in geothermally active regions are typically interpreted to be caused by heat transport via local convection (e.g., by circulating fluids), which is a more efficient means of heat transport than conduction. Alternatively, variation in thermal conductivity can generate conductive temperature anomalies. Downhole-equilibrated temperature measurements are the most reliable temperature data. Examination of the profile shape of equilibrated temperature logs (e.g., Ingebritsen 
and Manning 2010) is the most reliable indicator of convection versus conduction. The reader is directed to (Stimac et al. 2015), which detailed the interpretation of downhole temperature profiles. Shallow wells may also identify an upwelling zone, but they commonly describe an outflow plume as opposed to a deep-seated upwelling (e.g., Fig. 2). Fluid chemistry and aqueous geothermometers, either traditional (Fournier and Truesdell 1973; Fournier and Potter 1979; Giggenbach 1988) or multicomponent (Peiffer et al. 2014; Spycher et al. 2014; Palmer et al. 2015), as calculated from surficial or well fluids, can be useful indicators of reservoir temperatures and help to constrain the location(s) of upwelling zones versus outflow. Reservoir temperature estimates based on geothermometry, however, can have a variety of noteworthy uncertainties (see Ferguson et al. 2009 for a review of the uncertainties associated with aqueous geothermometry) that need to be considered in any interpretation.

The location and extent of surficial springs, fumaroles, tufa, travertine, sinter, silicified or calcified sediments, hydrothermal alteration, and diffuse degassing may also indicate high-temperature upwelling zones. Opaline sinter is clear evidence of Holocene sinter deposition (i.e., a very young system). Other geothermal deposits may represent young outflow, but they can be associated with older geothermal activity as well, so relative or absolute age determination is critical. As is the case, with shallow temperature data, surficial geothermal features and deposits may be associated with distal outflow of geothermal fluids rather than a deeply rooted local upwelling (e.g., Fig. 2) and should therefore be incorporated into interpretations with this in mind.

\section{Evaluating geothermal potential in 3D}

Once a 3D geologic map is constructed, it can be evaluated for localized geothermal potential using the above characteristics that are linked to permeability and fluid flow. The values in 3D space of each proxy are normalized on a zero-to-one scale, with zero the lowest geothermal potential and one the highest. The normalized proxies are summed to semi-quantitatively evaluate the locations where positive indications for geothermal circulation are most highly collocated with one another (Fig. 3). We do this, as opposed to quantitatively scaling the different proxies relative to one another (e.g., Ito et al. 2017; Lautze et al. 2017; Siler et al. 2017), because we cannot quantitatively constrain with site-specific data at either Tuscarora or Neal Hot Spring how, for example, upwelling potential or geothermal production potential associated with critically stressed faults quantitatively relates to upwelling potential associated with fault terminations or fault intersections.

Slip and dilation tendencies and fault intersection/tip density are normalized such that the most poorly oriented fault segment and the lowest density of fault intersections/terminations have geothermal potential value of zero. The most ideally oriented fault segment and the area of highest fault intersection/termination density have a geothermal potential value of one. For lithology, a binary rating is typically used. Favorable lithologic intervals, as indicated by lithologic, pressure-temperature-spinner, geothermal production, or well construction data (i.e., where the well is cased off or left open to flow from the formation) have a geothermal potential value of one, and other units in the stratigraphic section are assigned a geothermal potential value of zero. 


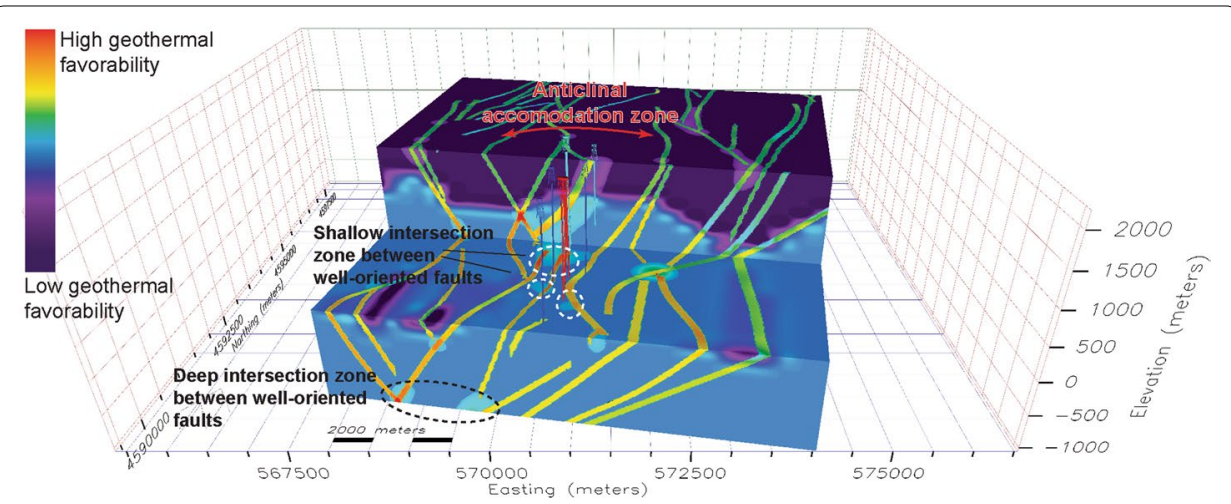

Fig. $123 \mathrm{D}$ geothermal potential map of the Tuscarora geothermal system. Warm colors, which are associated with the collocation of favorably oriented fault segments, high fault intersection/fault termination, and the Paleozoic basement section, indicate high geothermal potential. The dashed outlined areas of high geothermal potential are interpreted as the most likely locations for geothermal fluid upwelling. Geothermal production wells (red) and injection wells (dark blue are the proximal, light blue are the distal injection wells) are shown

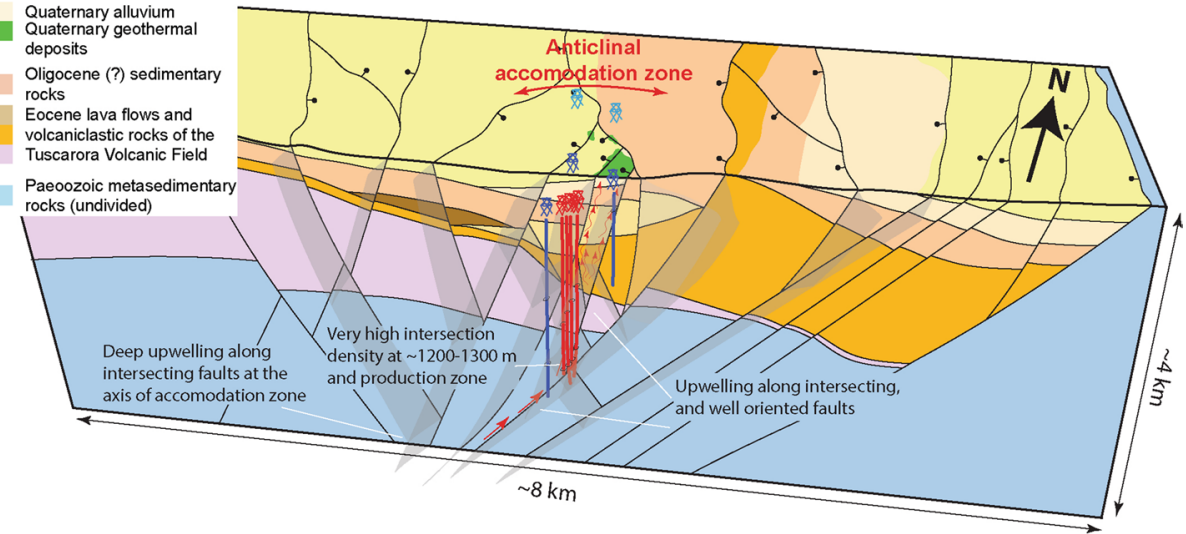

Fig. 13 Conceptual model of fluid upwelling at Tuscarora. Red wells are production wells; dark blue wells are the proximal injection wells; light blue wells are the distal injection wells. Deep upwelling (larger red arrows) occurs from high fault intersection/fault termination density in the axial part of the anticlinal accommodation zone at $\sim 3-5 \mathrm{~km}$ depth. Fluids upwell along fault intersections, and well-oriented (with respect to the regional stress field), NNE-striking/moderately to steeply dipping fault segments. Another area of relatively high fault intersection/fault termination density occupies the axial part of the accommodation zone at 1200-1300 m depth. The production wells (red) produce fluid from this area. Upwelling continues through the Cenozoic volcanic section, though upwelling through this section is likely diffuse (small red arrows). Fluids outflow at the active hot springs and Quaternary opaline sinter (green). Dark blue injection wells are in communication with the production wells; distal light blue injection wells are not in communication with production wells, as evidenced by tracer tests (Chabora et al. 2015)

The normalized slip tendency map, dilation tendency map, and intersection density maps are summed to produce a 3D map of the proxies related to structural permeability. Where summed with the lithologic favorability map, the resultant 3D map displays the relative variation in the potential for fracture permeability throughout the fault system based on the distribution of the proxies examined. These 3D geothermal potential maps have relatively high values where the geologic characteristics are conducive to geothermal fluid flow and low values where structural and lithologic conditions are not likely to 


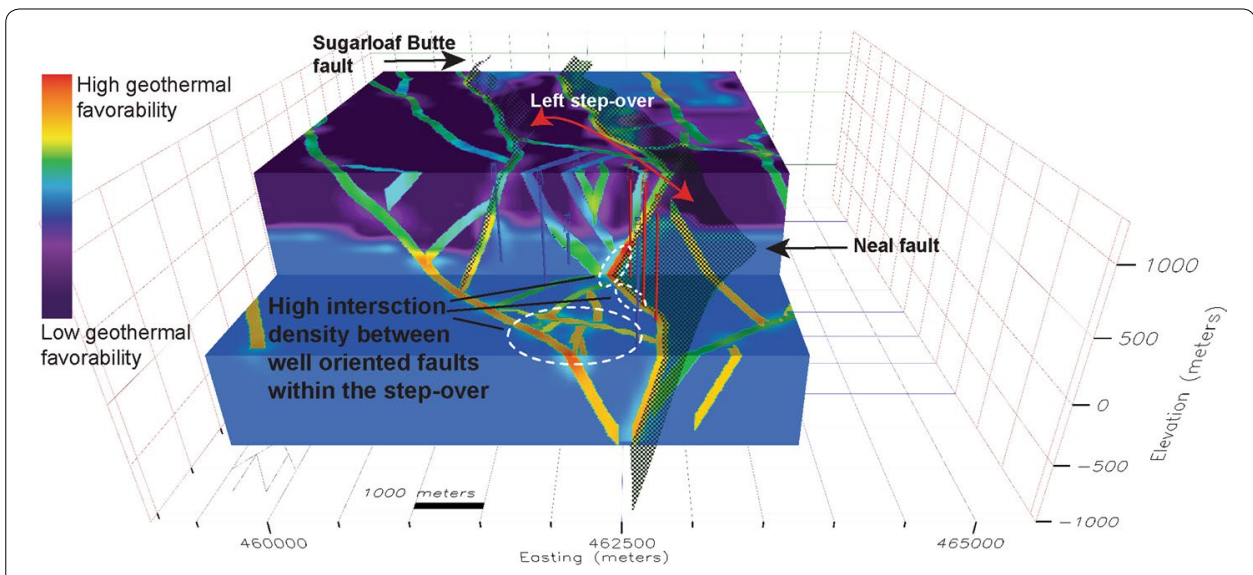

Fig. 14 3D geothermal potential map of Neal Hot Springs. Warm colors represent high potential are are associated with favorably oriented fault segments, high fault intersection/fault termination density, and the Columbia River Group volcanic section. The white-dashed outlined area of high geothermal potential is interpreted as the most likely location for geothermal fluid upwelling associated with geothermal production at Neal

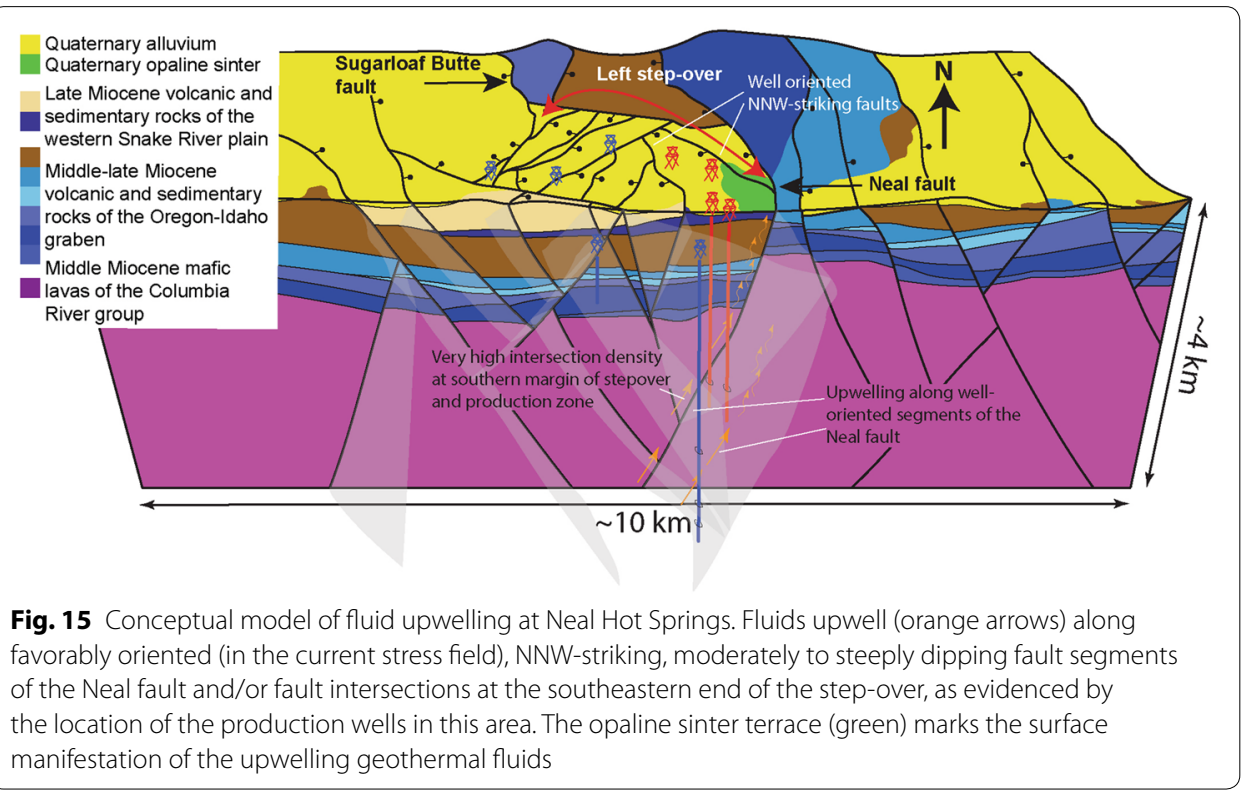

conduct upflow (e.g., Figs. 12, 13, 14, 15). We compare these results to any existing temperature data, surface geothermal expression, and fluid flow data to define areas where the geologic characteristics are conducive to permeability generation and temperatures suggest fluid circulation.

\section{Results and discussion}

\section{Tuscarora, Nevada}

The 3D geologic analysis of Tuscarora indicates that geothermal upwelling is likely sourced from intersecting faults with opposing polarity in the axial part of an accommodation zone (Dering 2013). 3D geothermal potential analysis builds upon these results 
and provides additional constraints on the character and location of fluid upwelling. The densest zone of intersecting faults lies in the axial part of the accommodation zone at $3000 \mathrm{~m}$ depth, several hundred meters deeper than and to the northwest of the current production zone (Fig. 11). The position of this zone of highest intersection density is subject to uncertainties in fault dip. Below and offset from the deepest wells, the precise location of this zone of highest intersection density is relatively uncertain, with respect to shallower structure in the central part of the geothermal field (e.g., Fig. 7b). The deep intersection zone is within the Paleozoic basement section, and the high slip and dilation tendency indicates that the intersecting faults are near optimally oriented for failure within the modern stress field.

Fluids upwell from this area along discrete faults that are well oriented in the regional stress field to shallower levels $(\sim 1200-1300 \mathrm{~m}$, still in the Paleozoic basement). Here, fault intersections between oppositely dipping fault segments form another northsouth elongate area of relatively high fault intersection density. These opposing faults have relative high slip and dilation tendency and are therefore appropriately oriented to be critically stressed. This corresponds to the bottom-hole location of the four main production wells at Tuscarora (Fig. 12). Fluids continue to upwell along well-oriented fault segments and fault intersections to the near surface, having built the Quaternary silica sinter deposits and supplying fluid flow to the modern hot springs (Fig. 13). The north-south elongate zone of relatively high intersection density extends northward for $\sim 1.25 \mathrm{~km}$ from the southern injection well, through the tightly spaced production wells, to the proximal injection wells to the northeast and northwest, but it does not extend to the northernmost, distal injection wells $\sim 1.5 \mathrm{~km}$ to the north (Fig. 12). Published tracer test data suggest that fluids flow between the four production wells and the proximal injection wells (Chabora et al. 2015). These results are consistent with the along-strike dimensions of the $\sim 1200-1300 \mathrm{~m}$ deep zone of high intersection density. The distal injection wells are apparently beyond the dense zone of well-oriented and intersecting faults in which the production wells and proximal injetion wells are located.

\section{Neal Hot Springs, Oregon}

The 3D geologic analysis of Neal Hot Springs indicates that geothermal upwelling is controlled by a complexly faulted, hard-linked left step-over between two overlapping westdipping normal fault zones (Edwards and Faulds 2012; Edwards 2013). 3D geothermal potential analysis adds additional details to this interpretation. The complexly faulted relay ramp within the step-over is an area of relatively high fault intersection density, suggesting relatively high fracture permeability in this area. The highest intersection density occurs along the southern margin of the step-over. In this area many fault intersections lie between the Neal and the Sugarloaf Butte faults. This includes intersections between north-northwest-striking normal faults, north-northeast-striking normal faults, and a west-northwest-striking fault within the step-over (Figs. 14, 15). This area of highest intersection density occurs as a series of steeply north-plunging columns lying between the two north-striking normal faults that bound the step-over, the Neal and the Sugarloaf Butte faults. 
Under the applied stress field, the north-northwest-striking Neal and Sugarloaf Butte faults on the eastern and western margins of the step-over, respectively, are generally well-oriented for slip and dilation. At the southern margin of the step-over, the Neal fault bends $\sim 10^{\circ}$ westward and thereby has relatively higher slip and dilation tendency to the north than to the south, indicating a higher potential for fracture permeability and fluid flow. Two northwest-striking faults, which have the highest slip and dilation tendency of faults within the step-over, intersect with the Neal fault in this area as well. This collocation of the high intersection density within the step-over, as well as the intersection between optimally oriented smaller faults and an optimally oriented section of the Neal fault, results in the highest geothermal favorability within the Neal Hot Springs 3D geothermal potential map. As a result of the highest density of well data and 2D seismic reflection data through this area, the geologic geometries here are relatively well constrained (Fig. 8b). The four production wells intersect the Neal fault within the middle Miocene mafic Columbia River Group volcanic section in this area, and the Quaternary silica sinter lies directly up-dip along the Neal fault from this high potential zone, suggesting that this area transmits geothermal fluids to the production wells, surficial hot springs, and sinter terrace (Fig. 15).

\section{Conclusions}

Geothermal energy will be an important component of future energy production in the USA and worldwide. Continued growth of geothermal development depends on the efficient development of known geothermal systems and discovery and development of new, blind, and otherwise unknown geothermal resources. In the western USA and around the world, discovery, assessment, and development of these resources depend on integrating temperature data with accurately characterized complex 3D structural and stratigraphic geometries. 3D geologic maps and 3D geothermal potential maps can aid these efforts. Data supported and testable 3D conceptual models based on the types of analyses presented herein can be developed, tested, and adapted throughout the exploration and development of geothermal fields. This study illustrates the importance of defining the detailed 3D geometry of fault systems (e.g., the relative stress state of fault segments and the geometries of fault terminations and fault intersections) in understanding the complex details associated with geothermal upwelling. These analyses were conducted with a relatively robust collection of data, coverage that may only be available in well-explored and/or developed systems. Even so, with both extensive and sparse subsurface data, and appropriate consideration of the density of data and uncertainties of the subsurface interpretations, accurate 3D maps of subsurface geology and geothermal potential can be constructed. The insights gained through application of these methods can be coalesced into working conceptual models and utilized for planning exploration and development strategies in prospective and operating structurally controlled geothermal fields. 


\section{Authors' contributions}

DLS constructed the 3D geologic maps and 3D geothermal potential models with the assistance of JF, NH, GD, JE, and BM. DLS wrote the manuscript. GD preformed 2D geologic mapping, analyses of core and cuttings, cross-sectional construction, and geothermal analyses at Tuscarora. JE preformed 2D geologic mapping, analyses of core and cuttings, cross-sectional construction, and geothermal analyses at Neal Hot Springs. JF supervised the projects at Tuscarora and Neal Hot Springs and field checked and/or reviewed maps, cross sections, and interpretations. All authors read and approved the final manuscript.

\section{Author details}

${ }^{1}$ U.S. Geological Survey, 345 Middlefield Rd MS 989, Menlo Park, CA 94025, USA. ${ }^{2}$ Nevada Bureau of Mines and Geology, University of Nevada, Reno, 1664 N. Virginia St., Reno, NV 89557, USA. ${ }^{3}$ Present Address: Geologica Geothermal Group Inc., 5 Third St, Suite 420, San Francisco, CA 94103, USA. ${ }^{4}$ Present Address: Centre for Exploration Targeting, University of Western Australia, 35 Stirling Highway, Crawley, WA 6009, Australia. ${ }^{5}$ Present Address: University of California, Santa Cruz, 1156 High Street, Santa Cruz, CA 95064, USA.

\section{Acknowledgements}

This work was supported through multiple sources of funding, including the Great Basin Center for Geothermal Research at the University of Nevada, Reno, the U.S. Department of Energy (Agreement No. DE-FG36-02ID14311) awarded to Faulds, and an American Recovery and Reinvestment Act grant from the U.S. Department of Energy (Agreement No. EE0002748) awarded to Faulds. The Neal Hot Springs work was also supported by Geological Society of America and Nevada Petroleum and Geothermal Society grants awarded to Edwards. We thank U.S. Geothermal Inc. for allowing access to their Neal Hot Springs data. The Tuscarora work was facilitated by Ormat Technologies, Inc., especially Peter Drakos, as well as through scholarships from ExxonMobil, the Nevada Petroleum and Geothermal Society, and American Association of Petroleum Geologists awarded to Dering. This work was also supported by Lawrence Berkeley National Laboratory under U.S. Department of Energy, Assistant Secretary for Energy Efficiency and Renewable Energy, Geothermal Technologies Program under the U.S. Department of Energy contract number DE-AC02-05CH11231. We thank Dynamic Graphics Inc., Alameda, California, for providing access to Earthvision 3D software. The assistance and advice of Robert McFaul was invaluable in development of the 3D mapping and geothermal favorability mapping workflows.

\section{Competing interests}

The authors declare that they have no competing interests.

\section{Availability of data}

The 1:24,000 scale geologic map, cross sections and supporting data from the Tuscarora area (Dering 2013; Dering and Faulds 2013b) are available at https://gdr.openei.org/submissions/357. The digital files of the 3D geologic map for Tuscarora are available at https://gdr.openei.org/submissions/366. The 1:24,000 scale geologic map, cross sections, and supporting data from the Neal Hot Springs area (Edwards and Faulds 2012; Edwards 2013) are available at https://gdr. openei.org/submissions/360. The digital files of the 3D geologic map for Neal Hot Springs are available at https://gdr. openei.org/submissions/364.

\section{Publisher's Note}

Springer Nature remains neutral with regard to jurisdictional claims in published maps and institutional affiliations.

Received: 19 June 2018 Accepted: 22 December 2018

Published online: 29 January 2019

\section{References}

Alberti M. 3D point cloud density calculation: a C++ program. 2011.

Anders MH, Wiltschko DV. Microfracturing, paleostress and the growth of faults. J Struct Geol. 1994;16:795-815. https:// doi.org/10.1016/0191-8141(94)90146-5.

Anderson RB, Faulds JE, Dering GM. Preliminary geologic map of the central Lake Range, southern Fox Range, and northern Terraced Hills, Emerson Pass geothermal area, Washoe County, Nevada, Nevada Bureau of Mines and Geology, Open-File report 13-10, scale 1:24,000. 2014.

Arnadottir T, Jonsson S, Pedersen R, Gudmundsson GB. Coulomb stress changes in the South Iceland Seismic Zone due to two large earthquakes in June 2000. Geophys Res Lett. 2003;30:10-3. https://doi.org/10.1029/2002GL016495.

Barton CA, Zoback MD, Moos D. Fluid flow along potentially active faults in crystalline rock. Geology. 1995;23:23-7. https ://doi.org/10.1130/0091-7613(1995)023\%3c0683.

Bergman SC, Blackwell DD, Goff F, Kennedy BM, McKenna JR, Richards MC, Smith RP, Waibel AF, Wannamaker PE. Dixie valley synthesis. Dallas: SMU Geothermal Laboratory; 2015.

Bibby HM, Caldwell TG, Davey FJ, Webb TH. Geophysical evidence on the structure of the Taupo Volcanic Zone and its hydrothermal circulation. JVolcanol Geotherm Res. 1995;68:29-58. https://doi.org/10.1016/0377-0273(95)00007 $-H$.

Blackwell DD, Steele JL, Carter LL. Heat-flow patterns of the North American continent; A discussion of the Geothermal Map of North America. In: Slemmons DB, Engdahl ER, Zoback MD, Blackwell DD, editors. Neotectonics of North America decade map, vol. 1. Boulder: Geologic Society of America; 1991. p. 423-36.

Blackwell DD, Wisian KW, Benoit WR, Gollan B. The Dixie valley geothermal system, a "typical" basin and range geothermal system, from thermal and gravity data. Geotherm Resour Council Trans. 1999;23:525-31.

Blake K, Davatzes NC. Crustal stress heterogeneity in the vicinity of Coso Geothermal Field, CA. In: Proceedings, thirty-fifth workshop on geothermal reservoir engineering, Stanford University. 2011. p. 914-24. 
Blakely RJ. Potential theory in gravity and magnetic applications. Cambridge: Cambridge University Press; 1996.

Blakely RJ, Connard GG. Crustal studies using magnetic data. Geol Soc Am Mem. 1989;172:45-60.

Bond CE. Uncertainty in structural interpretation: lessons to be learnt. J Struct Geol. 2015;74:185-200. https://doi. org/10.1016/j.jsg.2015.03.003.

Bond CE, Gibbs AD, Shipton ZK, Jones S. What do you think this is? "Conceptual uncertainty" in geoscience interpretation. GSA Today. 2007;17:4-10. https://doi.org/10.1130/GSAT01711A.1.

Brace WF. Permeability of crystalline and argillaceous rocks. Int J Rock Mech Min Sci Abstr. 1980;17:241-51.

Caine JS, Forster CB. Fault zone architecture and fluid flow: insights from field data and numerical modeling. Geophys Monogr Am Geophys Union. 1999;113:101-28.

Caine JS, Evans JP, Forster CB. Fault zone architecture and permeability structure. Geology. 1996;24:1025-8. https://doi. org/10.1130/0091-7613(1996)024\%3c1025.

Caine JS, Bruhn RL, Forster CB. Internal structure, fault rocks, and inferences regarding deformation, fluid flow, and mineralization in the seismogenic Stillwater normal fault, Dixie Valley, Nevada. J Struct Geol. 2010;32:1576-89. https:// doi.org/10.1016/j.jsg.2010.03.004.

Calcagno P, Chilès J-P, Courrioux G, Guillen A. Geological modelling from field data and geological knowledge: part I. Modelling method coupling 3D potential-field interpolation and geological rules. Phys Earth Planet Inter. 2008;171:147-57.

Chabora E, Lovekin J, Spielman P, Krieger Z. Resource Performance at Ormat's Tuscarora Geothermal Project, Nevada USA. In: Proceedings of the World Geothermal Congress, vol. 8. 2015.

Colwell CR. Integrated geophysical exploration of a known geothermal resource: Neal Hot Springs [M.S. Thesis]. Boise State University. 2013. https://doi.org/10.1190/segam2012-1543.1.

Coolbaugh MF, Sladek C, Faulds JE, Zehner RE, Oppliger GL. Use of rapid temperature measurements at a 2-meter depth to augment deeper temperature gradient drilling. In: Proceedings, thirty-second workshop on geothermal reservoir engineering, Stanford University, vol. 8. 2007.

Cowie PA, Scholz CH. Displacement-length scaling relationship for faults: data synthesis and discussion. J Struct Geol. 1992;14:1149-56.

Cumming W, Mackie R. 3D MT resistivity imaging for geothermal resource assessment and environmental mitigation at the glass mountain KGRA, California. Geotherm Resour Council Trans. 2007;31:331-4.

Curewitz D, Karson JA. Structural settings of hydrothermal outflow: fracture permeability maintained by fault propagation and interaction. J Volcanol Geotherm Res. 1997;79:149-68. https://doi.org/10.1016/S0377-0273(97)00027-9.

Curewitz D, Karson JA. Geological consequences of dike intrusion at mid-ocean ridge spreading centers. In: Buck WR, editor. Faulting and magmatism at mid-ocean ridges, geophysical monograph 106. Washington, DC: American Geophysical Union; 1998. p. 117-36.

Dering GM. Structural controls of the Tuscarora geothermal field, Elko County, Nevada. 2013.

Dering GM, Faulds JE. Structural controls of the Tuscarora geothermal field, Elko County, Nevada. Geotherm Resour Council Trans. 2013a;36:41-6.

Dering GM, Faulds JE. Preliminary geologic map of the Tuscarora geothermal area, Elko County, Nevada. Nevada Bureau of Mines and Geology, Open-File report 2013-05, scale 1:24,000. 2013b.

Edwards JH. Structural controls of the Neal Hot Springs geothermal system, eastern Oregon [M.S. Thesis]. University of Nevada, Reno. 2013.

Edwards JH, Faulds JE. Preliminary assessment of the structural controls of Neal Hot Springs geothermal field, Malhuer County, Oregon. Geotherm Resour Council Trans. 2012;36:891-6.

Fairley JP, Hinds JJ. Rapid transport pathways for geothermal fluids in an active Great Basin fault zone. Geology. 2004:32:825-8. https://doi.org/10.1130/G20617.1

Fairley JP, Heffner J, Hinds J. Geostatistical evaluation of permeability in an active fault zone. Geophys Res Lett. 2003;30. https://doi.org/10.1029/2003GL018064.

Faulds JE, Hinz NH. Favorable tectonic and structural settings of geothermal systems in the Great Basin Region, western USA: proxies for discovering blind geothermal systems. In: Proceedings of the World Geothermal Congress, vol. 6. 2015.

Faulds JE, Coolbaugh MF, Vice GS, Edwards ML. Characterizing structural controls of geothermal fields in the northwestern Great Basin: a progress report. Geotherm Resour Council Trans. 2006;30:69-76.

Faulds JE, Coolbaugh MF, Benoit WR, Oppliger GL, Perkins M, Moeck I, Drakos PS. Structural controls of geothermal activity in the northern Hot Springs mountains, western Nevada: the tale of three geothermal systems (Brady's, Desert Peak, and Desert Queen). Geotherm Resour Council Trans. 2010a;34:675-84.

Faulds JE, Moeck I, Drakos PS, Zemach E. Structural Assessment and 3D geologic modeling of the Brady's geothermal area, Churchill County (Nevada, USA): a preliminary report. In: Proceedings, thirty-fifth workshop on geothermal reservoir engineering, Stanford University. 2010b. p. 298-302.

Faulds JE, Hinz NH, Coolbaugh MF, Cashman PH, Kratt C, Dering GM, Edwards J, Mayhew B, Mclachlan H. Assessment of favorable structural settings of geothermal systems in the Great Basin, Western USA. Geotherm Resour Council Trans. 2011;35:777-84.

Faulds JE, Ramelli AR, Garside LJ, Coolbaugh MF, Green HL. Preliminary geologic map of the desert peak Quadrangle, Churchill County, Nevada. Nevada Bureau of Mines and Geology Open-File Report 12-5, scale 1:24,000. 2012.

Faulds JE, Hinz NH, Dering GM, Siler DL. The hybrid model—the most accommodating structural setting for geothermal power generation in the Great Basin, western USA. Geotherm Resour Council Trans. 2013;37:4-10.

Faulds JE, Ramelli AR, Coolbaugh MF, Hinz NH, Garside LJ, Queen JH. Preliminary geologic map of the Bradys geothermal area, Churchill County, Nevada. Nevada Bureau of Mines and Geology, Open-File Report 17-4, scale 1:12,000. 2017.

Ferguson G, Grasby SE, Hindle SR. What do aqueous geothermometers really tell us? Geofluids. 2009;9:39-48. https://doi. org/10.1111/j.1468-8123.2008.00237.x.

Ferrill DA, Winterle J, Wittmeyer G, Sims D, Colton S, Armstrong A, Horowitz AS, Meyers WB, Simons FF. Stressed rock strains groundwater at Yucca Mountain, Nevada. GSA Today. 1999;9:1-8.

Flóvenz ÓG, Sæmundsson K. Heat flow and geothermal processes in Iceland. Geothermics. 1993;225:123-38. 
Flynn T, Buchanan PK. Geothermal fluid genesis in the Great Basin. University of Nevada, Reno, NV (USA). Division of Earth Sciences Report. 1990.

Fournier RO, Potter RW. Magnesium correction to the Na-K-Ca chemical geothermometer. Geochim Cosmochim Acta. 1979;43:1543-50. https://doi.org/10.1016/0016-7037(79)90147-9.

Fournier RO, Truesdell AH. An empirical Na-K-Ca geothermometer for natural waters. Geochim Cosmochim Acta. 1973;37:1255-75.

Geldart LP, Gill DE, Sharma B. Gravity anomalies of two-dimensional faults. Geophysics. 1966;31:372-97.

Giggenbach WF. Geothermal solute equilibria. Derivation of Na-K-Mg-Ca geoindicators. Geochim Cosmochim Acta. 1988;52:2749-65. https://doi.org/10.1016/0016-7037(88)90143-3.

Goff F, Bergfeld D, Janik CJ, Counce D, Murrell M. Geochemical data on waters, gases, scales, and rocks from the Dixie valley region, Nevada (1996-1999). Los Alamos National Lab, No. LA-13972-MS. 2002.

Henry CD, Faulds JE. Ash-flow tuffs in the Nine Hill, Nevada, paleovalley and implications for tectonism and volcanism of the western Great Basin, USA. Geosphere. 2010;6:339-69. https://doi.org/10.1130/GES00548.1.

Hickman SH, Davatzes NC. In-situ stress and fracture characterization for planning of an EGS stimulation in the Desert Peak Geothermal Field, Nevada. In: Proceedings, Thirty-Fifth Workshop on Geothermal Reservoir Engineering, Stanford University, vol. 13. 2010.

Hickman S, Zoback MD, Benoit WR. Tectonic controls on reservoir permeability in the Dixie valley, Nevada, geothermal field. In: Proceedings, twenty-third workshop on geothermal reservoir engineering, Stanford University. 1998. p. 291-8.

Hinz NH, Faulds JE. Preliminary geologic map of the reese river geothermal area, Lander County, Nevada. Nevada Bureau of Mines and Geology, Open-File report 2011-03, scale 1:24,000. 2011.

Hinz NH, Faulds JE, Bell JW. Preliminary geologic map of the Bunejug Mountains Quadrangle, Churchill County, Nevada. Nevada Bureau of Mines and Geology Open-File Report 11-9, scale 1:24,000. 2011.

Hinz NH, Faulds JE, Coolbaugh MF. Association of fault terminations with fluid flow in the salt wells geothermal field, Nevada, USA. Geotherm Resour Council Trans. 2014;38:3-10.

Houlding S. 3D geoscience modeling: computer techniques for geological characterization. Berlin: Springer Science \& Business Media; 2012.

Ingebritsen SE, Manning CE. Permeability of the continental crust: dynamic variations inferred from seismicity and metamorphism. Geofluids. 2010;10:193-205. https://doi.org/10.1111/j.1468-8123.2010.00278.x.

Ito T, Zoback MD. Fracture permeability and in situ stress to $7 \mathrm{~km}$ depth in the KTB Scientific Drillhole. Geophys Res Lett. 2000;27:1045-8

Ito G, Frazer N, Lautze N, Thomas D, Hinz N, Waller D, Whittier R, Wallin E. Play fairway analysis of geothermal resources across the state of Hawaii: 2. Resource probability mapping. Geothermics. 2017;70:393-405.

Jachens RC, Wentworth CM, Gautier DL, Pack S. 3D geologic maps and visualization: a new approach to the geology of the Santa Clara (Silicon) Valley, California. U.S. Geological Survey Open-File Report 01-223. 2001. p. 13-23.

Jacobsen LJ, Glynn PD, Phelps GA, Orndorff RC, Bawden GW, Grauch VJS. Chapter 13: U.S. geological survey: a synopsis of three-dimensional modeling. In: Berg RC, Mathers SJ, Kessler H, Keefer DA, editors. Synopsis of current threedimensional geological mapping and modeling in geological survey organizations. Illinois State Geologic Survey; 2011. p. 69-92.

Jolie E, Faulds JE, Moeck I. The development of a 3D structural-geological model as part of the geothermal exploration strategy - a case study from the Brady's geothermal system, Nevada, USA. In: Proceedings, thirty-seventh workshop on geothermal reservoir engineering, Stanford University. 2012. p. 421-5.

Jolie E, Klinkmueller M, Moeck I. Diffuse surface emanations as indicator of structural permeability in fault-controlled geothermal systems. J Volcanol Geotherm Res. 2015a;290:97-113.

Jolie E, Moeck I, Faulds JE. Quantitative structural-geological exploration of fault-controlled geothermal systems-a case study from the Basin-and-Range Province, Nevada (USA). Geothermics. 2015b;54:54-67. https://doi.org/10.1016/j. geothermics.2014.10.003.

Jolie E, Klinkmueller M, Moeck I, Bruhn D. Linking gas fluxes at Earth's surface with fracture zones in an active geothermal field. Geology. 2016;44:187-90.

Krueger, J.I., Funder, D.C. Towards a balanced social psychology: causes, consequences, and cures for the problem-seeking approach to social behavior and cognition. Behav Brain Sci. 2004;27:313-27.

Lachenbruch AH, Sass JH. Heat flow in the United States and the thermal regime of the crust. In: Heacock JG, editor. The nature and physical properties of the earth's crust. American Geophysical Union Monograph; 1977. p. 626-75.

Lautze N, Thomas D, Waller D, Frazer N, Hinz N, Apuzen-Ito G. Play fairway analysis of geothermal resources across the state of Hawaii: 3. Use of development viability criterion to prioritize future exploration targets. Geothermics. 2017;70:406-13.

Lechler PJ, Coolbaugh MF. Gaseous emissions from Steamboat Springs, Brady's Hot Springs, and Desert Peak Geothermal Systems, Nevada. Geotherm Resour Council Trans. 2007;31:359-61.

Lindsay MD, Jessell MW, Ailleres L, Perrouty S, de Kemp E, Betts PG. Geodiversity: exploration of 3D geological model space. Tectonophysics. 2013;2013(594):27-37. https://doi.org/10.1016/j.tecto.2013.03.013.

Louie JN, Pullammanappallil SK, Honjas W. Advanced seismic imaging for geothermal development. In: New Zealand geothermal workshop 2011 proceedings, Auckland, New Zealand, vol. 7. 2011.

Meller C, Kohl T. The significance of hydrothermal alteration zones for the mechanical behavior of a geothermal reservoir. Geotherm Energy. 2014;2:12. https://doi.org/10.1186/s40517-014-0012-2.

Micklethwaite S, Cox SF. Fault-segment rupture, aftershock-zone fluid flow, and mineralization. Geology. 2004;32:813-6. https://doi.org/10.1130/G20559.1.

Micklethwaite S, Ford A, Witt W, Sheldon HA. The where and how of faults, fluids and permeability-insights from fault stepovers, scaling properties and gold mineralisation. Geofluids. 2015;15:240-51. https://doi.org/10.1111/ gfl.12102.

Mitchell TM, Faulkner DR. Towards quantifying the matrix permeability of fault damage zones in low porosity rocks. Earth Planet Sci Lett. 2012;339-340:24-31. https://doi.org/10.1016/j.epsl.2012.05.014. 
Moeck IS. Catalog of geothermal play types based on geologic controls. Renew Sustain Energy Rev. 2014;37:867-82. https://doi.org/10.1016/j.rser.2014.05.032.

Moeck I, Kwiatek G, Zimmerman G. Slip tendency analysis, fault reactivation potential and induced seismicity in a deep geothermal reservoir. J Struct Geol. 2009a;31:1174-82. https://doi.org/10.1016/j.jsg.2009.06.012.

Moeck I, Schandelmeier ÆH, Holl H. The stress regime in a Rotliegend reservoir of the Northeast German Basin. Int J Earth Sci. 2009b;98:1643-54. https://doi.org/10.1007/s00531-008-0316-1.

Moeck I, Hinz N, Faulds JE, Bell JW, Kell-hills A, Louie J. 3D geological mapping as a new method in geothermal exploration: a case study from central Nevada. Geotherm Resour Council Trans. 2010;34:807-12.

Moeck IS, Beardsmore G. A new 'geothermal play type' catalog: streamlining exploration decision making. In: Proceedings, thirty-ninth workshop on geothermal reservoir engineering, Stanford University, vol. 39. 2014. p. 1-8.

Morris A, Ferrill DA, Henderson DB. Slip-tendency analysis and fault reactivation. Geology. 1996;24:275-8.

Munoz G. Exploring for geothermal resources with electromagnetic methods. Surv Geophys. 2014;35:101-22.

Nathenson M, Guffanti M. Geothermal gradients in the conterminous United States. J Geophys Res Solid Earth. 1988;93:6437-50.

Newman GA, Gasperikova E, Hoversten GM, Wannamaker PE. Three-dimensional magnetotelluric characterization of the Coso geothermal field. Geothermics. 2008;37:369-99. https://doi.org/10.1016/j.geothermics.2008.02.006.

Nordquist J, Delwiche B. The McGinness hills geothermal project. Geotherm Resour Council Trans. 2013;37:57-64. Norton D, Knapp R. Transport phenomena in hydrothermal systems; the nature of porosity. Am J Sci. 1977;277:913-36.

Palmer CD, Ohlym RS, Smith RW, Neupane G, McLing T, Mattson E. Mineral selection for multicomponent equilibrium geothermometry. Geotherm Resour Council Trans. 2015;38:7.

Peacock JR, Thiel S, Reid P, Heinson G. Magnetotelluric monitoring of a fluid injection: Example from an enhanced geothermal system. Geophys Res Lett. 2012;39. https://doi.org/10.1029/2012GL053080.

Peiffer L, Wanner C, Spycher N, Sonnenthal EL, Kennedy BM, lovenitti J. Optimized multicomponent vs. classical geothermometry: insights from modeling studies at the Dixie Valley geothermal area. Geothermics. 2014;51:154-69. https ://doi.org/10.1016/j.geothermics.2013.12.002.

Peška P, Zoback MD. Compressive and tensile failure of inclined well bores and determination of in situ stress and rock strength. J Geophys Res Solid Earth. 1995;100:12791-811.

Phelps GA, Graymer RW, Jachens RC, Ponce DA, Simpson RW, Wentworth CM. Three-dimensional geologic map of the Hayward fault zone, San Francisco Bay region, California. US Geol Surv Scientific Invest Map. 2008;3045:35.

Pollard DD, Aydin A. Progress in understanding jointing over the past century. Progress in understanding jointing over the past century. Geol Soc Am Bull. 1988;100:1181-204. https://doi.org/10.1130/0016-7606(1988)100\%3c1181.

Queen JH, Daley TM, Majer EL, Nihei KT, Siler DL, Faulds JE. Surface reflection seismic and vertical seismic profile at Brady's Hot Springs, NV, USA. In: Proceedings, forty-first workshop on geothermal reservoir engineering, Stanford University, vol. 14. 2016.

Richards MC, Blackwell DD. A difficult search: why basin and range systems are hard to find. Geotherm Resour Council Bull. 2002;31:143-6.

Rowland JV, Sibson RH. Structural controls on hydrothermal flow in a segmented rift system, Taupo Volcanic Zone, New Zealand. Geofluids. 2004;4:259-83. https://doi.org/10.1111/j.1468-8123.2004.00091.x.

Sanderson DJ, Zhang X. Stress-controlled localization of deformation and fluid flow in fractured rocks. Geol Soc Lond Spec Publ. 2004;231:299-314.

Scholz CH, Dawers NH, Yu J, Anders MH, Cowie PA. Fault growth and fault scaling laws: preliminary results. J Geophys Res. 1993;98:951-61.

Sheldon HA, Micklethwaite S. Damage and permeability around faults: implications for mineralization. Geology. 2007:35:903-6. https://doi.org/10.1130/G23860A.1.

Sibson RH. Crustal stress, faulting and fluid flow. In: Parnell J, editor. Geofluids: origin, migration and evolution of fluids in sedimentary basins, Geological Society, London, Special Publications. 1994. p. 69-84.

Sibson H. Structural permeability of fluid-driven fault-fracture. J Struct Geol. 1996;18:1031-42.

Siler DL, Faulds JE. Three-dimensional geothermal fairway mapping: examples from the western Great Basin. USA: Geotherm Resour Council Trans; 2013a.

Siler DL, Faulds JE. Three-dimensional geothermal fairway mapping: examples from the western Great Basin, USA. Geotherm Resour Council Trans. 2013b;37:327-32.

Siler DL, Mayhew B, Faulds JE. Three-dimensional geologic characterization of geothermal systems: Astor Pass, Nevada, USA. Geotherm Resour Council Trans. 2012;36:783-6.

Siler DL, Faulds JE, Mayhew B, McNamara DD. Analysis of the favorability for geothermal fluid flow in 3D: Astor Pass geothermal prospect, Great Basin, northwestern Nevada, USA. Geothermics. 2016a;60. https://doi.org/10.1016/j. geothermics.2015.11.002.

Siler DL, Hinz NH, Faulds JE, Queen J. 3D analysis of geothermal fluid flow favorability: Brady's, Nevada, USA. In: The 41st workshop on geothermal reservoir engineering, Stanford University vol. 41. 2016b. p. 10.

Siler DL, Zhang Y, Spycher NF, Dobson PF, McClain JS, Gasperikova E, Zierenberg RA, Schiffman P, Ferguson C, Fowler A, Cantwell C. Play-fairway analysis for geothermal resources and exploration risk in the Modoc Plateau region. Geothermics. 2017;69. https://doi.org/10.1016/j.geothermics.2017.04.003.

Siler DL, Hinz NH, Faulds JE. Stress concentrations at structural discontinuities in active fault zones in the western United States: Implications for permeability and fluid flow in geothermal fields. Geol Soc Am Bull. 2018. https://doi. org/10.1130/B31729.1.

Smith GI, Friedman I, Veronda G, Johnson CA. Stable isotope compositions of waters in the Great Basin, United States 3. Comparison of groundwaters with modern precipitation. J Geophys Res Atmos. 2002;107:1-15.

Spycher N, Peiffer L, Sonnenthal EL, Saldi G, Reed MH, Kennedy BM. Integrated multicomponent solute geothermometry. Geothermics. 2014;51:113-23. https://doi.org/10.1016/j.geothermics.2013.10.012.

Stimac J, Goff F, Goff CJ. Intrusion-related geothermal systems. The encyclopedia of volcanoes. 2nd ed. Amsterdam: Elsevier; 2015. p. 799-822. 
Talwani M. Rapid gravity computations for two-dimensional bodies with application to the Mendocino submarine fracture zone. J Geophys Res. 1959;64:49-59.

Telford WM, Telford WM, Geldart LP, Sheriff RE. Applied geophysics. Cambridge: Cambridge University Press; 1990

Townend J, Zoback MD. How faulting keeps the crust strong. Geology. 2000;28:399-402. https://doi.org/10.1130/00917613(2000)28\%3c399:HFKTCS\%3e2.0.CO.

Uchida T, Sasaki Y. Stable 3D inversion of MT data and its application to geothermal exploration. Explor Geophys. 2006;37:223-30

U.S. Geological Survey. Quaternary fault and fold database for the United States, 2006. From U.S. Geological Survey website: http://earthquakes.usgs.gov/regional/qfaults/. Accessed Feb 2014.

Wallis IC, MCNamara D, Rowland JV, Massiot C. The nature of fracture permeability in the basement greywacke at Kawerau geothermal field, New Zealand. In: Proceedings, thirty-seventh workshop on geothermal reservoir engineering, Stanford University. 2012. p. 232-40.

Warren I. Exploration and development of the Neal Hot Springs geothermal resource, Malheur County, Oregon: search and discovery Article \#90266. AAPG Pacific Section and Rocky Mountain Section Joint Meeting, Las Vegas, Nevada, October 2-5, 2016.

Williams CF, DeAngelo J. Evaluation of approaches and associated uncertainties in the estimation of temperatures in the upper crust of the Western United States. Geotherm Resour Council Trans. 2011;25.

Williams CF, Reed MJ, Mariner RH, DeAngelo J, Galanis SPJ. Assessment of moderate- and high-temperature geothermal resources of the United States. U.S. geological survey fact sheet 2008-3082. 2008.

Witter JB, Siler DL, Faulds JE, Hinz NH. 3D geophysical inversion modeling of gravity data to test the 3D geologic model of the Bradys geothermal area, Nevada, USA. Geotherm Energy. 2016;4:21. https://doi.org/10.1186/s4051 7-016-0056-6.

Zoback MD, Townend J. Implications of hydrostatic pore pressures and high crustal strength for the deformation of intraplate lithosphere. Tectonophysics. 2001;336:19-30. https://doi.org/10.1016/S0040-1951(01)00091-9.

Zoback MD, Barton CA, Brudy M, Castillo DA, Finkbeiner T. Determination of stress orientation and magnitude in deep wells. Int J Mech Min Sci acts. 2003;40:1049-76. https://doi.org/10.1016/j.jirmms.2003.07.001.

\section{Submit your manuscript to a SpringerOpen ${ }^{\circ}$ journal and benefit from:}

- Convenient online submission

Rigorous peer review

Open access: articles freely available online

- High visibility within the field

Retaining the copyright to your article

Submit your next manuscript at $\boldsymbol{\Delta}$ springeropen.com 